Review Article

\title{
Biodegradable Food Packaging Materials and Prospects of the Fourth Industrial Revolution for Tomato Fruit and Product Handling
}

\author{
S. M. Chisenga $\mathbb{D}^{1},{ }^{1}$ G. N. Tolesa $\mathbb{D}^{1,},{ }^{1,2}$ and T. S. Workneh ${ }^{1}$ \\ ${ }^{1}$ School of Engineering, Bioresources Engineering, University of KwaZulu-Natal, Pietermaritzburg, South Africa \\ ${ }^{2}$ Department of Food Science and Postharvest Technology, Haramaya Institute of Technology, Haramaya University, \\ Dire Dawa, Ethiopia \\ Correspondence should be addressed to S. M. Chisenga; chisengam@ukzn.ac.za
}

Received 6 September 2020; Revised 23 October 2020; Accepted 31 October 2020; Published 23 November 2020

Academic Editor: James Owusu-Kwarteng

Copyright (C) 2020 S. M. Chisenga et al. This is an open access article distributed under the Creative Commons Attribution License, which permits unrestricted use, distribution, and reproduction in any medium, provided the original work is properly cited.

\begin{abstract}
The environment and food safety are major areas of concern influencing the development of biodegradable packaging for partial replacement of petrochemical-based polymers. This review is aimed at updating the recent advances in biodegradable packaging material and the role of virtual technology and nanotechnology in the tomato supply chain. Some of the common biodegradable materials are gelatin, starch, chitosan, cellulose, and polylactic acid. The tensile strength, tear resistance, permeability, degradability, and solubility are some of the properties defining the selection and utilization of food packaging materials. Biodegradable films can be degraded in soil by microbial enzymatic actions and bioassimilation. Nanoparticles are incorporated into blended films to improve the performance of packaging materials. The prospects of the fourth industrial revolution can be realized with the use of virtual platforms such as sensor systems in authentification and traceability of food and packaging products. There is a research gap on the development of a hybrid sensor system unit that can integrate sampling headspace (SHS), detection unit, and data processing of big data for heterogeneous tomato-derived volatiles. Principal component analysis (PCA), linear discriminant analysis (LDA), and artificial neutral network (ANN) are some of the common mathematical models for data interpretation of sensor systems.
\end{abstract}

\section{Introduction}

The global population is about 7.8 billion in 2020 and is estimated to reach 10 billion in 2050 [1]. The increasing population, urbanization, variability in diet, and climate change put pressure on food security including postharvest of fresh produce. The major loss of fresh produce occurs at the postharvest stage [2]. The fresh produce including tomato fruit is perishable due to high moisture content [2]. Generally, postharvest losses $(30-50 \%)$ of the fresh produce are associated with handling, storage, and packaging. The bulk nature of produce along the supply chain makes it difficult to monitor and control losses. Nevertheless, digital technologies including smart packaging innovations are considered suitable for tracking and controlling postharvest losses. The application of these smart logistic technologies finds use in product traceability systems on information that relates the product to its genetic factors and environmental conditions [3]. Furthermore, IFPRI [3] stressed that digitalization focused on the ecosystem including agricultural production, processing, transportation, and market system can enhance the food value chain and improve competitiveness. This necessitated the concept of digitalization of logistic systems including food packaging and market services. However, the use of synthetic plastic materials in food packaging can have an adverse effect on climate and the environment [4]. Hence, ecofriendly packaging materials are increasingly becoming the alternative. Muller et al. [4] reported that polylactic acid and starch are potential materials to replace synthetic polymer films, i.e., plastics food packaging materials. Moreover, Jeevahan et al. [5] reported that edible biofilms are compostable and can be manufactured from the polysaccharides, 
proteins, and lipids. The production of edible biofilms is a recent approach to generate biodegradable food packaging safe to humans and the environment. In addition, Guerrini et al. [6] reported that biodegradable films have physicochemical and mechanical properties suitable to replace common polymerplastic applications. However, the food industries are facing a range of challenges from climate change, increasing consumer safety demands, and subsequent issues relating to government policies and legislative requirements [7]. The environmental concerns associated with the nonbiodegradable nature of plastic biopolymers are impacting negatively on the ecosystem. In view of this, there is an increasing demand to replace synthetic plastic materials with biodegradable materials. This review is aimed at gathering recent advances in biodegradable packaging film materials and their performance on the quality of tomato. The role of virtual technology and nanotechnology in the tomato supply chain is highlighted in response to fourth industrial revolution.

\section{Importance of Food Packaging}

The economic value of packaging is reflected in the packaging conversion industry, packaging supply chain, and in the retail industry. In 2015, the packaging industry recorded revenues of $\$ 839$ billion worldwide [8] and was projected to grow by $3.5 \%$ by 2020 . Western Europe and Americas are the largest consumers of packaging. The packaging industry contributes $\sim 2 \%$ to gross domestic product (GDP) of the South African economy. The global demand for bio-based food packaging material is forecasted to reach $\sim 1$ million tons per year by 2020 [9]. The packaging material is considered as the major component in the sustainable development goal number 12 focused on themes (climate action, ocean action, plastic pollution in the ocean, food loss and waste, and sustainable transport) that relate to sustainable consumption and production. Food packaging provides protection and preservation of food by making a physical barrier against contamination due to foreign matter and environmental-related factors. This ultimately contributes to extended shelf life of food product. Other functions include mechanical and physical strength, convenience, and communication through product labeling [10, 11]. The actors in the value chain specific to food packaging include food processors, farmers, retailers, and researchers [12]. Postharvest strategy of minimizing loss through the packaging of tomato along the supply chain results in extended shelf life, improved income, livelihood, and food security [13]. Recent development in novel food packaging is driven by consumer's demand for convenience, ready to eat food, shelf stability, and maintenance of food quality [14]. The plastic polymers have been utilized for food packaging material production due to their availability and simplicity of manufacturing [15]. The petroleum polymers are hardly degradable and thus causing defects in the ecosystem [15]. Moreover, O'Brine and Thompson [16] reported that polymer plastic materials may take over 100 years to decompose. Similarly, Webb et al. [17] reported that polymer plastics that are landfilled could take longer than 20 years with no change in the plastic property. Hence, there are developments to replace petroleum-derived plastic with biodegradable materials. The innovation and development of food packaging from renewable, compostable, and biodegradable to active and intelligent packaging were reported $[18,19]$. In addition, barrier properties, compatibility materials, and shelf life extension properties of the innovative packaging determine selection and utilization $[18,19]$. The environmental safety concerns are limiting the use of plastic films for packaging in the food industries. Consequently, biopolymer films are receiving attention due to their biodegradable properties.

\section{Overview of Biodegradable Packaging}

The utilization of biodegradable materials on the markets of North America, Europe, and Asia has grown in the range of 15-20\% CAGR from 2012 to 2017 [20] but the market data for Africa is not well established. Atarés and Chiralt [21] reported the application of essential oil in biodegradable food packaging films in Spain for the production of bio-based packages with potential health benefits (antioxidants and antimicrobial properties). The lipid nature of essential oils can decrease water vapor permeability in hydrophilic materials and can also improve the structural, mechanical, and optical properties of packaging films. The biodegradable packaging films developed and tested on tomato fruit in Finland for preservation objectives resulted in extended shelf life [22]. In Malaysia, Ali et al. [23] demonstrated the use of gum arabic as edible coating film for extending the shelf life and postharvest quality of tomato. Starch edible coatings derived from Colombian native potatoes were applied on Andean blueberry (a wild fruit native to South America) resulting in reduced respiration rate of $\sim 27 \%$ [24]. However, previous works recommended further research focused on the improvement of the physical strength of biodegradable films comparable to that of petroleum polyfilms [22]. Sanaa and Medimagh [25] reported biomass materials that can be used to produce biodegradable and biopolymer in Africa: the vegetable cellulose extracts from cotton fibers in South Africa; Luffa Cylindrica in Nigeria; Washingtonian filifera in Algeria; Napier grass in Botswana; Hibiscus sabdariffa in Kenya, Ethiopia, and Uganda. The biopolymers such as chitosan, cellulose, and pectin were given attention in the manufacturing sector of food packaging and the research community [25]. Moreover, in Ethiopia, the film produced from pectin and chitosan extract and tested on tomato resulted in extended shelf life (15-17 days) compared to the control (10 days). Furthermore, in Nigeria, reports show that there is an intensive production of biodegradable plastic film from blending cassava starch and biodegradable polymer materials. Postharvest loss of fresh tomato on the market was reported to be 9.50, 9.80, and 10.04\% in Eastern, central, and southern African countries of sub-Saharan countries, respectively [13], with Kenya, South Africa, and Nigeria recording 10.10, 10.20 , and $13.40 \%$ postharvest losses, respectively [13]. Nevertheless, reduced postharvest losses among commercial or emerging farmers of tomato were achieved with the use of recyclable cardboard boxes of various sizes, bulk bins, plastic 
crates, and wooden crates for packaging and transportation in the South African supply chain [26].

Food packaging films can be produced either by lamination, casting, coextrusion, or coating processes from the raw plastic polymer, biopolymer, and biodegradable materials [10] (Table 1). The food packaging film is extracted from biopolymers, including gelatin, starch, cellulose, and bio-derived monomers such as polylactic acid [27]. The bacteria-derived compounds include cellulose, xanthan, curlan, and pullulan [19]. Chitosan is a natural polymer, nontoxic, edible, and biodegradable derived by deacetylation of chitin which is the second most abundant biopolymer in nature after cellulose [28]. Supplementation of different kinds of additives is recommended to improve the properties of the biodegradable film [27]. The edible biodegradable films can be stabilized by material components of hydrophilic nature such as proteins or polysaccharides. The production of films or coatings involves casting film-forming aqueous dispersions and subsequent drying. The essential oils (additives) are added to film during dispersion phase, and the mixture is achieved by homogenization or emulsification processes [21]. Thus, the dried polymer can be a structural matrix of the film and lipid droplets [21] including hydrocolloids such as edible fats, fatty acids, proteins, and polysaccharides [29]. Ivankovic et al. [19] reviewed that there are three generation stages of biodegradable polymers from which biodegradable food packaging materials can be manufactured. Accordingly, the first generation is low-density polyethylene (LDPE) film consisting of 5-15\% starch filters and autoxidative additives. The second-generation films are composed of 40-70\% pregelatinized starch, low-density polyethylene (LDPE), and hydrophilic copolymer additives. The third-generation materials are produced from biomaterials and can be classified into (a) polymer extracted from biomass such as starch, chitin, chitosan, plant proteins, and soybeans; (b) polymers synthesized from bio-derived monomers including polylactate and other polymers; and (c) biomonomers and polymers produced from natural or genetically modified organisms. The nanocomposite materials were identified to possess superior characteristics such as high performance, lightweight, and environmentally friendly compared to plastic food packaging materials [30]. The low cost, renewability, and availability of biopolymer are some of the desirable considerations applicable for thermoplastic starch-based food packaging materials [31].

The fruits coated with gum arabic soybean gum, jojoba wax, and glycerol resulted in delayed in changes of weight loss, firmness, and titratable acidity including delayed softening of tomato $[23,32]$. The tomato fruits coated with $10-15 \%$ gum arabic film yielded less weight loss during storage period than the control sample [23]. This suggests that gum arabic film exhibited effective semipermeable barrier against $\mathrm{O}_{2}$, $\mathrm{CO}_{2}$, moisture, and solute movement, which probably decreased respiration, water loss, and oxidation reaction rates. de Jesús Salas-Méndez et al. [33] reported that the mixture of edible coatings (whey protein, glycerol, and candelilla wax) and Fluorensia cernua extract coated on tomato inhibited $\sim 40 \%$ growth of pathogenic fungi. The mixture of $0.75 \%$ chitosan and $2 \mathrm{mM}$ cinnamic acid coated on tomatoes yielded high firmness after 12 days of storage [34]. The film made from chitosan colloids and grapefruit seed extract (0.5-1\%) inactivated Salmonella on cherry tomatoes during storage [35].

3.1. Preservation Mechanism of Edible Coatings. Quality deterioration of fruits is in function of biochemical processes in the cell structure, cell wall composition, and intracellular materials. Cellulase and polygalacturonase are two major cell wall hydrolase enzymes and were shown to correlate with softening and ripening of fruits [36]. Edible coating of fruits can delay ripening by lowering permeability of $\mathrm{O}_{2}$ resulting in increased intracellular $\mathrm{CO}_{2}$. High levels of $\mathrm{CO}_{2}$ can limit the activities of cell wall hydrolase enzymes and allow retention of the firmness during storage [23]. This effect of a lowoxygen environment is readily used for optimizing storage conditions and transport and for prolonging the shelf life of several fruit commodities [37]. Decreasing respiration rates of coated tomatoes could be responsible for delayed ripening and can result in reduced changes in physiological weight loss, color, titratable acidity, and retention of firmness [23]. The antimicrobial properties of edible coatings [38] can protect the fruit against firmness-degradative agents such insects and mites [39] which are carriers of fungal and bacterial spores [40] and can cause spoilage and softening of ripe tomato fruits [41]. The biodegradable packaging materials applied on fruits including tomato are decomposable and can be degraded by microorganisms in the soil $[6,42,43]$.

3.2. Biodegradation of Biodegradable Films. Soil microorganisms can degrade biodegradable materials into natural compounds such as water, carbon dioxide, and methane including monomers such as amine, alcohol, and carboxylate acid (Table 2). Biodegradability is in function of chemical composition, nature of bonding, and water availability. The appearance of IR spectra peaks for carbonyl signals is indicative of enzymatic degradation of starch into maltose (disaccharide) and glucose (monosaccharide) [44]. The microbial action is enzymatic nature. The microbial cells exhibit saprophytic growth utilizing plant-derived metabolites as substrates [45]. The microorganisms secrete an array of amylases and cellulases responsible for enzymatic hydrolytic and oxidative breakage of glycosidic bonds in starch and cellulose. The extracellular enzymes such as esterase, cutinase, and lipase hydrolyze labile aliphatic ester linkages of plasticizing films [46]. These enzymatic processes generate metabolites that are absorbed by microorganisms for energy requirements. This is evident in the decrease and disappearance of IR spectra carbonyl signals with time. Tai et al. [44] showed significant peaks of carbonyls in 30 days and decrease after day 45, which suggested starch/cellulose breakdown and metabolite absorption, respectively. Enzymatic depolymerization of chitosan showed a sharp increase of sugars with time during $15 \mathrm{~h}$ and slower in 15-24h [47]. The slower decrease of metabolites is indicative of the saprophytic phase. UV light irradiation with wavelength $<350 \mathrm{~nm}$ can cause chain scission of polymer molecules and can also accelerate enzymatic activity. Combined treatment of UV irradiation and cellulase enzyme degraded $60 \%$ of cellulose 
TABLE 1: Biodegradable packaging films and applications.

\begin{tabular}{|c|c|c|c|c|}
\hline Biodegradable film & Substrate & Production & Suitability for application & Reference \\
\hline $\begin{array}{l}\text { Polylactic acid } \\
\text { (PLA) }\end{array}$ & $\begin{array}{c}\text { Sugars or impure } \\
\text { carbon substrates } \\
\text { (starch, molasses, or } \\
\text { whey) }\end{array}$ & $\begin{array}{l}\text { Two-stage degradation processes: } \\
\text { (1) hydrolytic and (2) enzymatic }\end{array}$ & Compositing and lamination & $\begin{array}{l}\text { Nilsuwan } \\
\text { et al. [54] }\end{array}$ \\
\hline $\begin{array}{l}\text { Corn } \\
\text { starch/blueberry }\end{array}$ & $\begin{array}{l}\text { Corn starch, } \\
\text { blueberries } \\
\text { (Vaccinium } \\
\text { corymbosum L.) }\end{array}$ & $\begin{array}{c}\text { Starch extraction and production of } \\
\text { blueberry powder }\end{array}$ & $\begin{array}{l}\mathrm{pH} \text { indicator (rich in anthocyanin, } \\
\text { changes color in different } \mathrm{pH} \\
\text { conditions) }\end{array}$ & $\begin{array}{l}\text { Luchese et al. } \\
\qquad[55]\end{array}$ \\
\hline Starch/PLA canna & $\begin{array}{l}\text { Mixture of PLA, } \\
\text { compatibilizer, starch, } \\
\text { and zinc stearate }\end{array}$ & Mixing (miscibility) & $\begin{array}{c}\text { Thermal stability of antimicrobial } \\
\text { activity }\end{array}$ & $\begin{array}{l}\text { Mania et al. } \\
\text { [56]; Morales } \\
\text { and Calle [57] }\end{array}$ \\
\hline Cellulose nanofiber & Fruit fiber & $\begin{array}{c}\text { Steam pressure and water treatment } \\
\text { and neutralization and drying; wet } \\
\text { grinding }\end{array}$ & $\begin{array}{l}\text { High heat resistance, good discharge } \\
\text { capacity, and improved electrolyte } \\
\text { wettability }\end{array}$ & Sun et al. [58] \\
\hline Chitosan & $\begin{array}{l}\text { Shells of shrimps } \\
\text { (chitin) }\end{array}$ & $\begin{array}{l}\text { Washing shells, dried, and mesh } \\
\text { homogenizing; demineralization, } \\
\text { deproteinization, and deacetylation }\end{array}$ & $\begin{array}{l}\text { Coating, biocompatibility, } \\
\text { anticholesteremic, ion sequestering } \\
\text { actions, and antimicrobial activity }\end{array}$ & $\begin{array}{l}\text { De Queiroz } \\
\text { Antonino } \\
\text { et al. [59] }\end{array}$ \\
\hline $\begin{array}{l}\text { Chitosan/cassava } \\
\text { starch }\end{array}$ & $\begin{array}{l}\text { Cassava starch, } \sim 90 \% \\
\text { DD chitosan }\end{array}$ & $\begin{array}{l}\text { Two-stage processes: starch casting } \\
\text { and coating }\end{array}$ & Coating & $\begin{array}{l}\text { Bangyekan } \\
\text { et al. }[60]\end{array}$ \\
\hline Chitosan/PVA/PCL & $\begin{array}{l}\text { 83\% DD chitosan, } \\
\text { PVA, and PCL }\end{array}$ & $\begin{array}{c}\text { Dispersion processes, heating, and } \\
\text { mixing }\end{array}$ & Laminating and coating & Yar et al. [61] \\
\hline Chitosan/PVA & $\sim 85 \%$ DD chitosan & $\begin{array}{l}\text { Dispersion of chitosan and mixing; } \\
\text { crosslinking of mixture at freeze- } \\
\text { thaw cycles }\end{array}$ & & Bi et al. [62] \\
\hline Chitosan-fungal & $\begin{array}{l}\text { 75-85\% DD chitosan, } \\
\text { mushroom } \\
\text { (Tricholoma terreum) }\end{array}$ & $\begin{array}{l}\text { Mixing chitosan and mushroom } \\
\text { extract; film-forming by casting. }\end{array}$ & Antimicrobial and antioxidant & Koc et al. [63] \\
\hline Protein film & Dehydrated lentil & $\begin{array}{l}\text { Protein extraction and purification, } \\
\text { mixing, and thin casting }\end{array}$ & Crosslinked by transglutaminase & $\begin{array}{l}\text { Tinoco et al. } \\
{[64]}\end{array}$ \\
\hline Protein-lipid film & Soybean & $\begin{array}{l}\text { Extraction of soymilk slurry, ohmic } \\
\text { heating/water bath heating, and film } \\
\text { casting and drying }\end{array}$ & Improving hydrophilicity & Lei et al. [65] \\
\hline Ozone-starch film & Potato, ozone & $\begin{array}{c}\text { Starch extraction, dispersion, } \\
\text { ozonation, gelatinization, casting, } \\
\text { and drying }\end{array}$ & $\begin{array}{c}\text { Increases number of carbonyl and } \\
\text { carboxyl groups }\end{array}$ & $\begin{array}{l}\text { La Fuente } \\
\text { et al. [66] }\end{array}$ \\
\hline $\begin{array}{l}\text { Cassava } \\
\text { starch/evan film }\end{array}$ & $\begin{array}{c}\text { Starch, Bacillus } \\
\text { subtilis natto CCT } \\
7712\end{array}$ & Production of microbial levan & $\begin{array}{l}\text { Edible film, coating, antioxidant, anti- } \\
\text { inflammatory, anticarcinogenic, anti- } \\
\text { AIDS, and hyperglycaemic inhibitor }\end{array}$ & $\begin{array}{l}\text { Mantovan } \\
\text { et al. [67] }\end{array}$ \\
\hline
\end{tabular}

DD: degree of deacetylation.

acetate compared to UV treatment (23\%) in 7 weeks [48]. Biodegradation process is commonly characterized using thermalgravimetric analysis (TGA) reflected in three-stage degradation profiles; the first degradation corresponds to loss of water and volatiles, the second stage relates to the formation of starch subunits of lower molecular weight, and the third stage is associated with breakdown of starch components $[46,49]$. The degradation of biodegradation film is in function of microbial activity in soil and water, hydrophilic nature of plasticizer, surface area of the sample, crystallinity, molecular weight of the sample, and temperature. The addition of plasticizers increases the number of polar groups and water permeability in the samples and accelerates the interaction of polar groups with water [50]. Plasticizers of biosurfactant nature possess excellent surface/interface activity and biocompatibility [51] and enhanced soil hydrocarbon bio- degradation by lowering interfacial tension between soil and water [52]. Increased yields of metabolites such as volatile fatty acids were shown at optimal pH 10 under controlled fermentation process [51]. Higher $\mathrm{pH}$ levels can inhibit acidophilic bacteria and subsequently limiting the production of metabolites. The pulsed electric fields treated zein-chitosan-poly(vinyl alcohol) film had enhanced stability of films against electrolyte and enzyme degradation [53].

\subsection{Properties of Biodegradable Films}

3.3.1. Structural Properties. The chemical structures and composition of packaging materials can be examined using Fourier transform infrared (FT-IR) spectroscopy and atomic force microscopy (AFM) [72]. Diffraction method using Xray diffraction has been applied in the assessment and 
TABLE 2: Degradation methods of biodegradable material films.

\begin{tabular}{|c|c|c|c|}
\hline Film & Biodegradable medium & Biodegradability & Reference \\
\hline Starch & Aerobic biodegradation & $\begin{array}{l}60 \% \text { disintegration rate }\left(\mathrm{CO}_{2} \text { produced }\right) \text { in } \sim 10 \text { days; three- } \\
\text { stage TGAs: first degradation } \sim 61-63^{\circ} \mathrm{C}[68], \text { second } \\
\text { degradation } \sim 257^{\circ} \mathrm{C} \text {, and maximum disintegration } T_{\mathrm{p}} \\
\sim 280-290^{\circ} \mathrm{C}\end{array}$ & $\begin{array}{l}\text { Tampau } \\
\text { et al. [46] }\end{array}$ \\
\hline Cassava starch/yerba mate & $\begin{array}{l}\text { Decomposition: vegetal } \\
\text { compost }\end{array}$ & $\begin{array}{l}\text { Degradation time } 6-12 \text { days exhibited changes in tonality } \\
\text { and breakdowns materials. Three-stage TGAs: first } \\
\text { degradation } \sim 100-150^{\circ} \mathrm{C}[68] \text {, second degradation } \sim 180- \\
60^{\circ} \mathrm{C} \text {, and maximum disintegration } T_{\mathrm{p}} \sim 250-350^{\circ} \mathrm{C}\end{array}$ & $\begin{array}{l}\text { Jaramillo } \\
\text { et al. [49] }\end{array}$ \\
\hline Cassava starch/yerba mate & $\begin{array}{l}\text { Acid and alkaline } \\
\text { stability treatment }\end{array}$ & $\begin{array}{l}\text { Swelling capacity: } \sim 1.6 \text { in acid and }<1.9-2.2 \text { in alkaline } \\
\text { condition }\end{array}$ & $\begin{array}{l}\text { Jaramillo } \\
\text { et al. [49] }\end{array}$ \\
\hline Zein-chitosan-poly(vinyl alcohol) & $\begin{array}{l}\text { In vitro degradation } \\
\text { (enzymatic susceptibility) }\end{array}$ & $\begin{array}{l}\text { Amine content: } \sim 0.03 \mathrm{mM} \text { Scrine Eq in } 30 \mathrm{~min} \text {; amino acids } \\
\text { increase between } 60 \text { and } 260 \mathrm{~min}(0.08-0.04 \mathrm{mM} \text { Scrine Eq) }\end{array}$ & $\begin{array}{l}\text { Giteru } \\
\text { et al. [53] }\end{array}$ \\
\hline $\begin{array}{l}\text { Zein-chitosan-poly(vinyl } \\
\text { alcohol)_PEF treated (between } 60- \\
70 \mathrm{~kJ} / \mathrm{kg} \text { and } 600-620 \mathrm{~kJ} / \mathrm{kg} \text { ) }\end{array}$ & $\begin{array}{l}\text { In vitro degradation } \\
\text { (enzymatic susceptibility) }\end{array}$ & $\begin{array}{l}\text { Amine content: } \sim 0.02 \mathrm{mM} \text { Scrine Eq in } 30 \mathrm{~min} \text {; amino acids } \\
\text { increase between } 60 \text { and } 260 \mathrm{~min}(0.02-0.04 \mathrm{mM} \text { Scrine Eq). } \\
\text { Higher energy yielded higher amino acids }\end{array}$ & $\begin{array}{l}\text { Giteru } \\
\text { et al. [53] }\end{array}$ \\
\hline Poly(L-lactide) & $\begin{array}{l}\text { Combination of UV } \\
\text { irradiation and } \\
\text { enzymatic degradation }\end{array}$ & Erosion depth deepens with increasing degradation time & $\begin{array}{l}\text { Kikkawa } \\
\text { et al. [69] }\end{array}$ \\
\hline PLA & Hydrolytic degradation & $\begin{array}{c}\text { Increased mass loss as a function of immersion time }(t) \text { at } \\
\mathrm{pH}=10 \text {, complete degradation in } 288 \mathrm{~h} \text {; other } \mathrm{pH}=4 \text { and } 7 \\
\text { yielded no changes in mass loss }\end{array}$ & $\begin{array}{l}\text { Scaffaro } \\
\text { et al. [70] }\end{array}$ \\
\hline PLA/CRV & Hydrolytic degradation & Faster kinetics of hydrolytic reactions compared to PLA & $\begin{array}{l}\text { Scaffaro } \\
\text { et al. }[70]\end{array}$ \\
\hline Poly(vinyl alcohol)/chitosan & $\begin{array}{l}\text { Buried in the soil for } 30 \\
\text { days }\end{array}$ & $60 \%$ weight loss at 30 days & $\begin{array}{l}\text { Yu et al. } \\
\text { [71] }\end{array}$ \\
\hline Poly(vinyl alcohol)/chitosan $\mathrm{SiO}_{2}$ & $\begin{array}{l}\text { Buried in the soil for } 30 \\
\text { days }\end{array}$ & $\sim 40 \%$ weight loss at 30 days & $\begin{array}{c}\text { Yu et al. } \\
{[71]}\end{array}$ \\
\hline
\end{tabular}

TGA: thermalgravimetric analysis; CRV: carvacrol (CRV) essential oil (2-methyl-5-(1-methylethyl)-phenol); PEF: pulsed electric fields.

quantification of amorphous and crystalline structures in starch. The crystallinity is strongly associated with amylopectin molecule. Amylose is largely found in the amorphous lamellae, and amylopectin forms crystalline lamellae of the starch granule [73]. Crystallinity influences dispersion characteristics such as swelling of starch in plasticizers [73]. The IR spectrum is commonly characterized by the interaction of chemical bonding with IR radiations. IR spectrum for starch films exhibited broad band due to vibrational stretching of hydroxyl $(-\mathrm{OH})$ groups linked inter- and intrachain. The narrow bands were associated with stretching of $\mathrm{C}-\mathrm{H}$ bonds while the peaks related to carbonyl $(\mathrm{C}=\mathrm{O})$ groups attached to the ring of glucose [74]. The surface microscopic analyses of film structure were examined using scanning electron microscopy and transmission electron microscopy [75, 76]. Starch and PVA films exhibited homogenous and smooth surfaces. The cross-section of the films was the characteristic of heterogeneous and irregular (bubble like) structures which varied with degree of crystallinity. The film blends (PVA/starch) are characteristic of microstructure phase separation due to inadequate miscibility, differences in crystallinity, and extrusion method. Compatibilizer compounds such as formaldehyde and poly(ethylene glycol) are blended with films to prevent phase separation blended films [77]. Factors influencing phase separation include proportional of starch and phosphate groups in the amylopectin chain. Potato starch film did not exhibit phase separation owing to the presence of higher content of phosphate groups than other native starches. The thickness of the films determined using SEM was reported, and film blends showed higher thickness than pure starch. The differences in thickness were due to variation in molecular weight. Higher molecular weight yielded higher thickness [78]. Biodegradable edible packaging material (coating or film) has a recommended thickness of less than $254 \mu \mathrm{m}$ [9].

3.3.2. Permeability Properties. The polymer matrix must exhibit effective permeability of gases for increased shelf life of food products [29]. The shelf life and freshness of vegetables and fruits including tomato are directly related to the transfer of water between the produce and the surrounding atmosphere. Thus, the primary role of packaging is to reduce the transfer of water. The poor moisture barriers in edible films were due to the hydrophilic nature of polysaccharides [29]. Lipids are hydrophobic in nature, and their inclusion in chitosan and polysaccharide films contributes to improved water vapor barrier properties. The entanglement of hydrogen bonding between $\mathrm{NH}_{2}$ group of chitosan and $\mathrm{OH}$ group of plasticizers (e.g., CAP and PVA) increased hydrophobicity of blended films (CAP/chitosan and PVA/chitosan) resulting in six reductions in water transfer rate [79]. Furthermore, Yu et al. [79] demonstrated that the addition of silica 
nanoparticles into biodegradable films decreased permeability of moisture. Depending on the respiratory requirements of the product and polar molecular of packaging material ingredients, oxygen permeability properties can be altered by incorporating PVC, chitosan, and silica. Oxygen permeability values were reduced by $\sim 26 \%$ when silica was incorporated into PVA/chitosan biodegradable films [79]. The equilibrium-modified atmosphere packaging (EMAP) finds intensive application in the packaging of fresh fruit and vegetable including tomato. The EMA packaging optimizes gas transport properties according to the respiratory requirements of fresh produce. The equilibrium atmosphere is attained when the exchange of gases through the film is in steady state with the production or consumption of gases due to the respiration and transpiration processes of the fresh produce [72]. The gas transport properties can be adjusted by perforation through macroperforation and microperforation using mechanical and laser procedures, respectively [72]. Among the alternative biopolymers, starch and polylactic acid (PLA) are the major materials of interest in the research community.

3.3.3. Mechanical Properties. Zhou et al. [80] developed biodegradable polylactic films using pea starch and polylactic acid for cherry tomato packaging film. However, biodegradable polylactic film exhibits poor mechanical properties compared to petroleum polylactic films $[80,81]$. The biopolymers such as starch are associated with brittle films. The incorporated hydrophilic plasticizers such as polyols (glycerol, sorbitol, and polyethylene glycol) into film-forming dispersions decreased intermolecular forces and increased mobility of polymers resulting in increased flexibility and extensibility [82]. The mechanical properties (compression test, tensile strength, and strain) including film-forming capacity of the film are associated with polymer crystallinity and amylose content [82], molecular weight properties, and their distribution and concentration of additives. Plasticizing agents such as polyvinyl alcohol (PVA) and cellulose acetate phthalate (CAP) can change the mechanical behavior owing to the formation of inter- and intramolecular hydrogen bonds. The blend of starch and PVA yielded biodegradable film with better mechanical performance [83]. The film blend of chitosan$\mathrm{CAP}$ and nanoZnO recorded higher tensile strength than pure chitosan film [84]. The increase in tensile strength in film blends is indicative of better interaction among the components of the film. The tensile strengths of the films increased with increasing diblock copolymer [85]. Inclusion of plasticizers and nanoparticles into starch films increased and decreased elongation at break, respectively (Table 3). Nanofillers provide reinforcement and increase interfacial bonding interaction in the film matrix. Lower molecular weight yielded higher tensile strength and elongation at break of starch films. The decrease in brittleness can be achieved by blending PLA with plasticizers such as polycaprolactone (PCL) [86]. However, the PLA-PCL blends exhibited poor gas barrier properties but can be improved using suitable fillers such as highly dispersed nanoparticles [86]. There is a need for increased research objectives to improve the mechanical properties of the biodegradable polylactic film using nanoparticles in response to the respiratory requirements of tomato fruits. Rhim et al. [87] reported that drawbacks in biodegradable polylactic film limit their full utilization in the food industry. Some of the limitations are thermal instability, low heat sealability, brittleness, lowmelting length, and high water vapor and oxygen permeability [87]. Moreover, the hydrophilic nature of some biodegradable biopolymers was characterized with low water vapor barrier and consequently exhibiting weak mechanical properties [88, 89].

3.3.4. Solubility Properties. The solubility values of biodegradable films are in function of hydrophilic nature of polymers. The solubility of starch film $(0.208 \mathrm{~g}$ dissolved $/ \mathrm{g}$ dry film $)$ and PVA $\left(0.19 \mathrm{~g}_{\text {dissolved }} / \mathrm{g}_{\text {dry film }}\right)$ decreased in the film blend of PVA/starch $\left(0.11 \mathrm{~g}_{\text {dissolved }} / \mathrm{g}_{\text {dry film }}\right)$ [90]. This suggested a decrease in the hydrophilicity of the film matrix. The entanglement of hydrogen and hydroxyl bonding between polymers can lead to structural reorientation, thus exposing the hydrophobic nature of the film matrix and subsequently, decreasing water affinity. Nevertheless, Pellá et al. [91] reported higher water affinity of films in blended potato starch/PVA than those of pure films (Table 3). This was ascribed to an increase in -OH groups. Sajjan et al. [92] reported that lower solubility values are indicative of films with good stability in aqueous medium and are recommended for packaging applications especially for storage.

3.3.5. Optical Properties. The color parameters $\left(L^{*}, a^{*}\right.$, and $b^{*}$ ) and color difference $(\Delta E)$ are commonly measured using CIE system [93] while transmission of light and transparency [94] can be measured using UV Vis Spectrophotometer [93]. Prolonged exposure to UV and visible radiations can discolor and deteriorate the packaged food products. In view of this, transparency and UV-screening ability of packaging films are vital parameters in quality control. Generally, synthetic plastic films (low-density polyethylene and polypropylene) were reported to have lower screening ability against UV radiation [84]. The blended films loaded with nanoparticles exhibited higher absorption peaks (wavelength) than pure films. The higher surface area of nanoparticles increased the UV absorption capacity of the polymer matrix [75]. The nanocomposites ( $\mathrm{ZnO}$ and nanoclay) increased the opacity of starch films, suggesting that nanoparticles are UV blockers and thus minimize the penetration of light.

\section{Advances in Packaging Technology}

The packaging technologies for food applications include active, intelligent, smart, modified packaging, controlled packaging, and biodegradable coatings.

4.1. Active Packaging. Inclusion of antimicrobial components is an aspect of innovative food packaging technologies such as active and intelligent packaging [96-101]. Active packaging is material components with the capacity to protect the packaged food from microbial proliferation [102] and provide information about the quality during transport and storage. The petroleum-based polymeric materials are commonly applied in active packaging [103]. However, environmental 
TABLe 3: Properties of pure and blended biodegradable packaging films.

\begin{tabular}{|c|c|c|c|c|c|c|c|}
\hline Samples & OTR & WVTR (g/day/L) & Solubility & $\begin{array}{l}\text { Tensile } \\
\text { (MPa) }\end{array}$ & $\mathrm{EB}(\%)$ & $\begin{array}{l}\text { Thickness } \\
(\mu \mathrm{m})\end{array}$ & Reference \\
\hline Potato starch & & & 0.28 & 5 & 100 & 182 & $\begin{array}{c}\text { Gómez-Aldapa et al. } \\
{[83]}\end{array}$ \\
\hline $\mathrm{PVOH}$ & & & 0.25 & 35 & 650 & 109 & $\begin{array}{c}\text { Gómez-Aldapa et al. } \\
\text { [83] }\end{array}$ \\
\hline Potato starch: PVOH & & & $0.24-0.35$ & $6-15$ & $\begin{array}{l}110- \\
450\end{array}$ & $133-177$ & $\begin{array}{c}\text { Gómez-Aldapa et al. } \\
\text { [83] }\end{array}$ \\
\hline Polylactic acid (PLA) & 200 & 66 & & 45 & 2.5 & 100 & Ivonkovic et al. [95] \\
\hline PLA & & & & 38 & 16 & & \\
\hline PLA-CRV & & & & 24 & 29 & 57 & \\
\hline Chitosan $\mathrm{Mw}=300 \mathrm{kDa}$ & & $13 \times 10^{-11} \mathrm{~g} \mathrm{~m}^{-1} \mathrm{~s}^{-1} \mathrm{~Pa}^{-1}$ & & 20 & 20 & 71 & Liu et al. [78] \\
\hline Chitosan $\mathrm{Mw}=150 \mathrm{kDa}$ & & $14 \times 10^{-11} \mathrm{~g} \mathrm{~m}^{-1} \mathrm{~s}^{-1} \mathrm{~Pa}^{-1}$ & & 23 & 24 & 70 & Liu et al. [78] \\
\hline Chitosan $\mathrm{Mw}=50 \mathrm{kDa}$ & & $16 \times 10^{-11} \mathrm{~g} \mathrm{~m}^{-1} \mathrm{~s}^{-1} \mathrm{~Pa}^{-1}$ & & 25 & 28 & 69 & Liu et al. [78] \\
\hline Chitosan-kojic film & & $3-9 \times{ }^{1} 0^{-11} \mathrm{~Pa}^{-1} \mathrm{~g} \mathrm{~m}^{-1} \mathrm{~s}^{-}$ & & $25-55$ & $29-65$ & $90-124$ & Liu et al. [78] \\
\hline Chitosan film & & 6.6 & & 5 & 50 & & Khamhan et al. [85] \\
\hline Chitosan-nano* & & $5-6$ & & $7-12$ & $15-25$ & & Khamhan et al. [85] \\
\hline Chitosan & & & & 82 & 5.2 & & Suyatma et al. [28] \\
\hline Chitosan-PLA & & & & $52-72$ & $3.6-4.9$ & & Suyatma et al. [28] \\
\hline Chitosan & 1850 & 438 & & 8 & $\sim 13$ & & Indumathi et al. [84] \\
\hline Chitosan/CAP & 1832 & 390 & & $\sim 9$ & 29 & & Indumathi et al. [84] \\
\hline Chitosan/CAP-ZnO & $\begin{array}{l}1490- \\
1724\end{array}$ & $120-160$ & & $9-11$ & $15-26$ & & Indumathi et al. [84] \\
\hline
\end{tabular}

${ }^{*}$ Methoxy poly(ethylene glycol)- $b$-poly( $\varepsilon$-caprolactone) diblock copolymer, cellulose acetate phthalate (CAP); $\mathrm{O}_{2}$ TR: oxygen transfer rate at $0 \% \mathrm{RH}$; WVTR: water vapor transfer rate at 100\%; CRV: carvacrol (CRV) essential oil (2-methyl-5-(1-methylethyl)-phenol).

and safety concerns have driven research and development in packaging towards bioactive materials [103]. Active materials are intentionally added to packaging material or packaging headspace to prolong shelf life through a controlled release of antimicrobial compounds [104]. Active food packaging was developed to respond to the food market demand for improved quality of fresh produce and maintaining safety [96]. Tomato fruits preserved using active packaging resulted in extended shelf life [96], improved safety, and maintained sensory properties [97, 98]. Essential oils with antimicrobial and antioxidants activity are incorporated into food packaging films to produce active packaging materials and thus contributing to the preservation of the food [105]. Essential oils inhibit the growth of microorganisms [105]. Moreover, Azmai et al. [106] reported that coating with chitosan and cinnamic acid improved the quality attributes such as firmness and total soluble solids, reduced physiological weight loss of tomato, and prolonged the shelf life. However, global migration of compounds from packaging material into food is a food safety concern and can cause contamination [107]. Bradley et al. [108] postulated that intelligent food packaging can cause toxicological risk, environmental contamination, and problems with recovery and recycling of the packaging materials. The package of active biodegradable corrugated cardboard tray tested on cherry tomato was reported to extend the shelf life of tomato for a month [96].
4.2. Active Scavenging and Adsorbents. The liquid exudate from fresh tomatoes influences sensorial and microbial quality [109]. The adsorbent pads are designed to take up the exudate and ultimately preserving integrity and quality of packaged products [110]. The active scavenging systems remove gases such as $\mathrm{CO}_{2}, \mathrm{O}_{2}$, and ethylene from the package or container. The presence of oxygen in package accelerates oxidation or spoilage. The decreased reactive oxygen species was associated with delayed overripening and decreased susceptibility to Botrytis cinerea [111]. The role of scavenging was achieved using flavonoids produced from different tomato varieties [111]. Ethylene scavengers $\left(\mathrm{KMnO}_{4}\right.$, activated carbon, clay, and zeolites) have been applied on fruits and vegetables including tomatoes. The $\mathrm{KMnO}_{4}$ transforms ethylene into acetate and ethanol. Cherry tomato treated with $0.1 \%(\mathrm{v} / \mathrm{v})$ ethanol during storage resulted in elevated ascorbic acid, sucrose, and fructose contents, inhibited ripening, and improved sensorial quality [112]. The $\mathrm{KMnO}_{4}$-based technology has been reported to have a limited commercial application due to uncertainties on its effectiveness as postharvest tool and also concerns relating to health, environmental, and safety [113]. However, $\mathrm{KMnO}_{4}$-promoted nano zeolite was reported to show high ethylene removal efficiency [114]. The condensation due to transpiring tomatoes can lead to accumulation of moisture. The removal of moisture can be achieved using active element (silica gel, polyacrylate 
salts, zeolites, and microporous clays) in the packaging system [115]. A sodium polyacrylate-cotton mixture applied as moisture adsorbent in the form of sachets resulted in noncondensation of water in active packaging system of tomato fruits [115]. The preservative releasers based on the blend of itaconic acid and chitosan enriched with tomato bioactive extract yielded significant antimicrobial effects on packaging films [116]. Other preservative releasers applied in packaging system for tomato include silver zeolite, organic acids, spice/herb extract, vitamins $\mathrm{C}$ and $\mathrm{E}$, sorbates, chlorine dioxide/sulfur dioxide, and benzoates and propionates [117].

4.3. Intelligent and Smart Packaging for Tomatoes. Intelligent packaging is a packaging that comprises of external or internal indicators that give information about the history on safety and quality of the product [104]. Vanderroost et al. [118] reviewed that smart or intelligent packaging technologies offer the opportunity to record and detect changes in the packaged product and its environment [118]. Intelligent packaging tracks the history of the food along the supply chain [97]. For instance, Bartkowiak et al. [119] reported that the lactic acid-based time-temperature indicators [102] provided history on quality and time-temperature of lactic acid-based food. Hence, this application can find use in tomato and tomato-derived products that are acidic in nature. However, a few of such technologies were commercialized, partly due to higher cost of investment. Lee et al. [97] suggested low-cost intelligent packaging material production for food industries.

\section{The Fourth Industrial Revolution in Packaging and Tomato Supply Chain}

The major technological drivers for the fourth industrial framework (4IR) are physical, digital, and biological technologies [120]. The appropriate technology driver for packaging and tomato supply chain is digital technology which includes fields such as artificial intelligence and robotics, linked sensors (Internet of Things), virtual and augmented realities, additive manufacturing (3D bioprinting organic tissues), advanced materials, and nanomaterials [121]. In agricultural production, the digital technology finds application in areas of smart sensing and monitoring, smart control, smart analysis, and planning [122]. The notable digital technology in packaging and tomato supply chain is the use of sensors and electronic nose for classification and discrimination of germplasm of food crops, quality control, and verification and authentification of geographical origin. Traditionally, wet extraction and analysis is a common laboratory approach of obtaining key trait information about tomato germplasm in different agroecological zones; however, this approach involves the use of chemicals which are detrimental to the environment and human safety. Levin [121] outlined methodological approach required to achieve smart sensing digital systems in the quality analysis of food crops: (i) sample handling systems, (ii) detection systems, and (iii) data processing systems (Table 4).
5.1. Sample Handling System. The conventional isolation techniques for volatile compounds such as steam distillation and solvent extraction can cause modification to quantity and quality of flavor profiles in samples [123]. In addition, these techniques are destructive and time-consuming. The rapid techniques include the purge and trap headspace sampling method $[123,124]$. The headspace can be in static or dynamic mode. This method involves trapping and concentrating volatile compounds on a solid support which is then heated to release volatiles into gas chromatography (GC) or GC/mass spectrometer (MS) systems containing sensing elements. The purge and trap and dynamic headspace sampling were used to extract the flavor compounds from tomato fruits $[125,126]$. The static headspace sampling methods in tomatoes [127] extracted a true reflection of flavor profile but yielded low amounts of compounds, suggesting loss of volatiles during sample handling and may result in undetection. Such shortcomings were eliminated with the use of cold trapping static headspace. This cryofocusing technique allows samples to be concentrated without heating. The solid-phase microextraction (SPME) is a user-friendly preconcentration method. In this technique, volatile components interact and react with fiber-coated probe inserted into the headspace of a sample and then transferred to a GC injection port where the volatiles are desorbed. The SPME has been applied in the analysis and discrimination of volatiles in tomato landraces [128]. The stir bar sorptive extraction is another sampling technique in which a magnetic bar coated with polymers is suspended in the headspace. This technique is similar to inside-needle dynamic extraction method, a preconcentration technique in which absorbing polymers are fixed inside the needle, and enables the interaction of polymers with volatiles [129]. The mechanism of volatile release, different types, and factors guiding the selection of stir bar sorptive were reported [129].

5.2. Detection System. The detection system is the application of an array of sensors operating as devices to identify chemical compounds in the headspace. Chemical sensor transforms chemical quantity into an electrical signal in function of the concentration of specific atoms, molecules, or ions in gaseous or liquid forms [124, 130]. The sensors applied in e-nose are capable of responding to molecules or particles which are volatile in nature and can vary with relative molar masses. Several sensor arrays used in the development of enose have been reported. Piezoelectric sensor is a device that utilizes acoustic waves generated by piezoelectric materials such as quartz or $\mathrm{LiNbO}_{3}$ [130] to detect changes in pressure, acceleration, temperature, strain, or force and converting them to an electrical charge [131]. The acoustic (piezoelectric) impulse response parameters (dominant frequency, firmness index, and elasticity coefficient) yielded a good to strong correlation with firmness parameters (compression force and puncture force) of tomatoes during storage time [131]. Electrochemical sensors are devices that convert electrochemical reactions between an electrode and analyte into an output signal specifically related to the concentration or partial pressure of the gaseous species [132]. The types of electrochemical sensors include potentiometric, conductometric, 
TABLE 4: Application of sensors in tomato and fruits.

\begin{tabular}{|c|c|c|c|c|c|}
\hline Sample & Objective & Sampling & Detection & $\begin{array}{c}\text { Data } \\
\text { processing }\end{array}$ & Reference \\
\hline $\begin{array}{l}\text { Tomato } \\
\text { (heat wave) }\end{array}$ & Discrimination between ripeness states & SHS & $\begin{array}{l}\text { Libra nose: } \\
5 \text { QMBs }\end{array}$ & PCA & $\begin{array}{l}\text { Peris and Escuder- } \\
\text { Gilabert [130] }\end{array}$ \\
\hline $\begin{array}{l}\text { Tomato } \\
\text { (heat wave) }\end{array}$ & Discrimination between ripeness states & SHS & $\begin{array}{l}\text { PEN 2: } 10 \\
\text { MOS }\end{array}$ & $\begin{array}{l}\text { PCA, LDA, } \\
\text { and PLS }\end{array}$ & $\begin{array}{l}\text { Peris and Escuder- } \\
\text { Gilabert [130] }\end{array}$ \\
\hline Heat wave & Discriminating shelf life during two storage treatments & SHS & $\begin{array}{l}\text { PEN 2: } 10 \\
\text { MOS }\end{array}$ & $\begin{array}{l}\text { PCA, LDA, } \\
\text { and PLS }\end{array}$ & $\begin{array}{l}\text { Peris and Escuder- } \\
\text { Gilabert [130] }\end{array}$ \\
\hline $\begin{array}{l}\text { Tomato } \\
\text { plants }\end{array}$ & Diagnosis of aphid-infested tomato plants & SPME & $\begin{array}{l}\text { GCMS- } \\
\text { QP2010 SE }\end{array}$ & PCA & Cui et al. [162] \\
\hline $\begin{array}{l}\text { Tomato } \\
\text { seedling }\end{array}$ & Detecting damage caused by mold and blight & SHS & $\begin{array}{l}\text { PEN 2: } 10 \\
\text { MOS }\end{array}$ & $\begin{array}{l}\text { PCA, LDA, } \\
\text { and BPNN }\end{array}$ & Cheng et al. [163] \\
\hline $\begin{array}{l}\text { Tomato } \\
\text { fruit }\end{array}$ & Classification of odours & SHS & EN: $6 \mathrm{MOS}$ & PCA & Kasbe et al. [164] \\
\hline Date pits & Assessing stability of 32 sensors & PTHS & $\begin{array}{l}\text { PEN: } 32 \\
\text { sensors }\end{array}$ & PCA & $\begin{array}{c}\text { Rahman et al. } \\
\text { [165] }\end{array}$ \\
\hline Tomato & Monitoring flavors & SHS & $\begin{array}{l}\text { PEN3: } 10 \\
\text { MOS }\end{array}$ & PCA, LDA & $\mathrm{Xu}$ et al. [166] \\
\hline Tomato & $\begin{array}{l}\text { Field phenotyping of key traits (SSC, glucose, fructose, TA, citric } \\
\text { acid, ascorbic acid, malic acid, and lycopene) }\end{array}$ & $\begin{array}{c}\text { ATR } \\
\text { surface }\end{array}$ & DTGS & PLSR & Akpolat et al. [167] \\
\hline Tomato & Evaluating ripening state & SHS & $\begin{array}{l}\text { PEN2: } 10 \\
\text { MOS }\end{array}$ & PCA & Gómez et al. [142] \\
\hline
\end{tabular}

PLSR: partial least squares regression; ATR: attenuated total reflectance; DTGS: deuterated-triglycine sulfate detector; SHS: static headspace; MOS: metal oxide sensors.

amperometric, and voltametric but they have limited detection limits [130, 132-134]. The recent areas of research in electrochemistry involve the modification of electrochemical sensors using conductive materials such as nanoparticles to enhance their response and detection limits [135]. The sensitivity of a conductive material-based sensor is defined by change in the electrical conductivity of the semiconducting material when exposed to test volatiles. Nanoparticles such as spherical $\mathrm{Cd}_{2} \mathrm{SnO}_{4}$ and $\mathrm{Zn}_{2} \mathrm{SnO}_{4}$ provide large surface area for the absorption and have high electron density [136]. The electrochemical DNA sensor was developed to perform the direct determination in intact genomic DNA extracted from tomato seeds [137]. This suggests that electrochemical sensor can be used to discriminate the bionature such as organic or inorganic germplasm in tomato cultivars. Other detection systems include and optical and thermal sensors. The optical sensors which include absorbance, reflectance, luminescence, and surface plasmon resonance techniques [138] are nondestructive methods based on multispectral three-dimensional (3D) imaging [139]. The fertilizer application and irrigation water were optimized based on the reflectance characteristics of the canopy such as leaf temperature, leaf relative water content, and leaf chlorophyll content in the field of tomato [138]. Thermal sensors detect heat produced by a specific analyte in the chemical reaction. The different types of heat sensors include resistance temperature detectors (RTDs), thermocouples, thermistors, infrared sensor, and semiconductor sensors. Thermal sensing depends on analyte change of state in response to temperature and light. The signals of optothermal window/light-emitting diode correlated strongly with colorrelated quality parameters of tomato-derived products [140].
The problem associated with e-nose is that they tend to produce limited information by targeting specific measurements. In real time, the food ground matrix (fresh or processed) is a complex of interacting volatile constituents. Peris and Escuder-Gilabert [130] proposed a sensor hybrid system to generate different sensor outputs in a single spectrum. Nevertheless, this would require the application of more complex electronics combined with standardized sensor outputs. The problem associated with e-nose such as masking of sample constituents, influence of moisture, and nonlinearity of signals were solved by integrating e-nose system with mass spectrometry. The MS-e-nose integrated systems are a new technology that introduces volatile compounds into the ionization chamber of MS-based instrument that produces an output of ion-fragmentation patterns [130] representing a chemical footprint for volatile compounds in a sample. The MS-based e-noses find application in qualitative analyses of alcoholic beverages.

5.3. Data Processing System. The sensor array output of samples is processed using pattern recognition techniques [141]. The interaction of volatile compounds with sensing elements produces changes in the electrical resistance of the sensor. The changes in electric signals are different depending on the sensor kinetics and thus a variety of signals collected and remitted into data acquisition and processing unit in which a volatile fingerprint can be interpreted using appropriate mathematical recognition techniques such as principal component analysis (PCA), linear discriminant analysis (LDA), and artificial neutral network (ANN). The discrimination of geographical origin and identification of different 


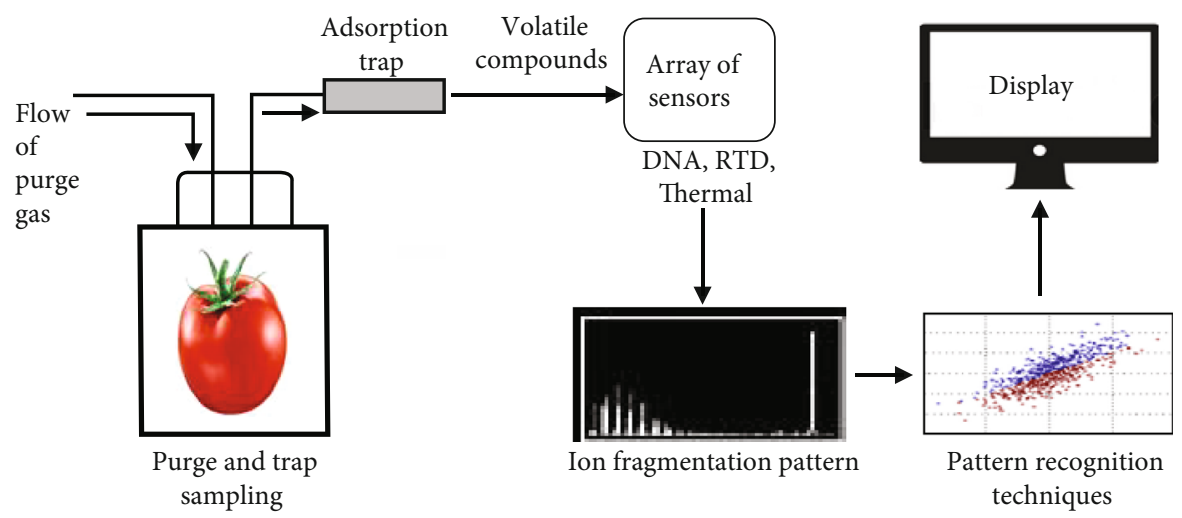

Figure 1: Traceability of tomato fruits in function of environmental conditions including soil fertility, geographical source, type of germplasm, type of coating, and postharvest distribution and storage conditions.

olive oil varieties were achieved based on metal oxide semiconductor sensor using PCA and LDA and yielded $~ 98 \%$ and $96 \%$ recognition success rates, respectively [141]. Optimization of recognition pattern requires the use of an array of sensors commonly in the range from 1 to 32 sensors. The sensors are evaluated using a loading analysis of PCA to identify significant patterns and their corresponding sensors. PEN2 with 10 different metal oxide sensors (MOS) was used to recognize the ripening state of tomato [142], and PCA biplot loadings showed that sensor MOS 2, 6, and 8 were located on the extreme positive coordinates of the biplot but MOS 2 had variance of $295 \%$ (please see figures in Gómez et al. [142]). This indicated that the three sensors were extremely distinguished; however, MOS 2 exerted higher influence on the ripening pattern of tomato. In addition, sensors 6 and 8 clustered together, which is an indicative of similarities in their response to ripening.

5.4. Applications of Virtual Platforms in Traceability. The conductivity of sensors is in function with changes in physicochemical characteristics of the product. The sensor PEN2 e-nose (Airsense Analytics, GmBH, Schwerin, Germany) was used to detect quality changes (soluble solids content, $\mathrm{pH}$, firmness, and vitamin $\mathrm{C}$ ) in juice extracted from cherry tomato [143]. In the same study, Hong and Wang [143] analyzed the sensorial characteristics of tomato juice using $\alpha$ Astree e-tongue (Alpha MOS Company, Toulouse, France). Berna et al. [144] compared two electronic nose systems, quartz microbalance-based electronic nose (E-nose) and a mass spectrometry-based electronic nose (MSE-nose) against gas chromatography (GC) as a standard reference in the analysis of aroma differences among tomato cultivars. The MSE-nose produced variation while E-nose hardly discriminated the differences among the cultivars [144]. The electronic sensories (e-nose and e-tongue) are commercial ready on the markets; however, their application would require validation studies specific to genetic factors, geographic locations, growth traits, and changes in postharvest handling and logistics. Other studies reported analysis of sourness, saltiness, and umami using electronic nose and electronic tongue coupled with gas chromatography-mass spectrometry (SPME/GC-MS) [145].
The unpredictable changes in supply chain, dynamics in quality, and regulatory system requirements for food safety and sustainability would require networked processes of virtualization to enable centralized operational management of food supply chains [146]. This is aimed at achieving a food supply chain that can be monitored, controlled, planned, and optimized in real-time using the Internet-based virtual objects instead of on-site physical observation [146]. The RFID (radio frequency identification), EPC global (Electronic Product Code), and ebXML (Electronic business using eXtensible Markup language) are some of the electromagnetic or electrostatic coupling technologies commonly applied to virtualization of supply chain traceability for commercial products including food and petroleum-based plastic materials. The European Union regulatory requirements for traceability of food contact materials are mandatory [147]. South Africa is among the major regional tomato producer in sub-Saharan Africa and ranks among the major exporters of fresh produce including tomato to the EU [148, 149]. However, no information relates to the traceability of biodegradable packaging materials in the South African tomato supply chain. The authentification of biodegradable packaging can be assured by developing a footprint characteristic of a material component to enable digital differentiation between biodegradable and synthetic plastic packaging materials. The biodegradable packaging materials are considered suitable for organically produced agricultural products including tomato. Literature showed that there are several benefits of supply chain traceability including enhanced integrity of a supply chain, easy tracking of product from farm to consumer, tracing of products to their origin, avoiding the risk of inappropriate labeling of products, and improves effectiveness of product audits.

There are concerns with packaging labeling regarding the misrepresentation of package, package ingredients, and false statements aimed at making an economic gain. This desire to gain a profit by mislabeling of products is a concern in the markets. Consumers are increasingly becoming aware of the value of food quality and safety. The contaminants resulting from nonbiodegradable packaging materials represent an important food safety topic $[150,151]$ and can lead to decreased consumer confidence in finished/processed food 
products. Subsequently, such safety concerns have stimulated interest in authentification and traceability for compliance with the regulations, consumer protection, and competition. The packaging products must reflect the origin of the material ingredients, details of postharvest treatments, and the geographic location (Figure 1). Turci et al. [152] reported that the internal traceability has been established as the reliable approach of preventing fraudulent or deceptive labeling and also to certify originality and quality of tomato products on the market and their postharvest influencing factors including packaging material nature. The commonly documented parameters for authentification and internal traceability for tomatoes are protein [153], metabolite [154], and DNA [152]. There is a need to identify nanoparticle makers for traceability and authentification of biodegradable materials.

The nanosensor signals expressed in nanometers are developed to detect changes in structural and functional properties of materials at nano level $\left(1 \mathrm{~nm}=10^{-9}\right)$ [155] and are embedded in food packaging material to monitor freshness of perishable products [156] during production, processing, and distribution. The suitability of nanomaterials is in function of good mechanical and electrical properties [157] and high surface area [155]. The tracking of food ingredients using nanosensor through the processing chain [158] suggests the potential application of nanodevices to monitor the ingredients of biodegradable materials. The structural differences between natural biopolymers and synthetic polymers [159] can be streamlined at nanoscale to develop differentiating markers. The data on structural and functional properties of material components in response to electromagnetic behavior can lead to the development of nanodevices to enable the identification of material ingredients and formulations. The biodegradable materials can be degraded by enzymatic action of living organisms (bacteria, yeasts, and fungi) and storage conditions (humidity and water). There is a gap in research for mathematical modeling relating to impact of degradability agents on the durability and mechanical integrity of biodegradable materials. The network of nanosensors can be implemented to achieve product monitoring and environmental conditions. The RFID and wireless sensor network (WSN) integration was suggested [160] to capture environmental information along with product tagging and thus assuring the end-user on meeting the system requirements throughout product delivery and storage such as maintaining the required temperature and humidity [160]. The loss of sensor data occurs due to corrupted network or hardware failure [160, 161]. The missing data can be predicted by data mining techniques [160] using interpolation methods: k-nearest neighbors (KNN) [161], global refinement method Delaunay Triangulation, PCA, multichannel singular spectrum analysis (MSSA), and compressive sensing [161]. The RFID-WSN can be integrated with data mining techniques to incorporate the data due to changes in the storage conditions. The novel environmental space-time improved compressive sensing (ESTI-CS) algorithm [161] achieved environmental reconstruction with a minimal error of $20 \%$ for $90 \%$ corrupted network. However, there is limited information on the implementation of nanosensor technology in integrated sensor system.

\section{Conclusions and Recommendations}

The demand to replace synthetic plastic with biodegradable packaging materials is increasing. The development of biodegradable packaging is influenced by several factors including policy and legislative changes and world demand for food and energy resources. The biodegradable materials are associated with poor properties (high brittleness and low transparency). Nevertheless, the use of nanocomposite ingredients can improve brittleness and other physical properties. There are limited studies focused on interactions between the polymers and the food products. In addition, there are few studies that point to toxicities associated with the global migration of ingredients from a biodegradable package into the food. The appreciable use of digital platforms in the tomato industry to attain objectives of 4IR would require great amount of data to develop a hybrid sensor response in function of production (agronomy and genetic traits), postharvest treatment, storage conditions (temperature and relative humidity), quality traits, and geographical origin of genetic factors. There is a need to develop fingerprint markers to enable differentiation and authentication of biodegradable materials.

\section{Conflicts of Interest}

The authors declare that they have no conflicts of interest regarding the publication of this paper.

\section{Acknowledgments}

The authors thank ZZ2 and the Tomato Producer Organization (TPO) for their assistance in the course of this study. This work was funded by the Postharvest Innovation Programme (PHI) under Grant number TPO Project 20 - 19. The authors would like to acknowledge Mr. Wiam Haddad and Mr. Manie Potgieter for the technical assistance provided during the planning of the experimental design and tomato sampling.

\section{References}

[1] United Nations, Department of Economic and Social Affairs, Population Division (2019), World Population Prospects 2019, United Nations, UN, 2019.

[2] A. Zekrehiwot, B. T. Yetenayet, and M. Ali, "Effects of edible coating materials and stages of maturity at harvest on storage life and quality of tomato (Lycopersicon Esculentum Mill.) fruits," African Journal of Agricultural Research, vol. 12, no. 8, pp. 550-565, 2017.

[3] IFPRI, Policy Seminar: Transforming Africa's Food System with Digital Technologies: Co-Organized by the Malabo Montpellier Panel and IFPRI D, Areba, Ed., Malabo Montpellier Panel and IFPRI Washington, DC, 2019.

[4] J. Muller, C. González-Martínez, and A. Chiralt, "Combination of poly (lactic) acid and starch for biodegradable food packaging," Materials, vol. 10, no. 8, p. 952, 2017.

[5] J. Jeevahan, M. Chandrasekaran, R. Durairaj, G. Mageshwaran, and G. B. Joseph, "A brief review on edible 
food packing materials," Journal of Global Engineering Problems and Solutions, vol. 1, no. 1, pp. 9-19, 2017.

[6] S. Guerrini, G. Borreani, and H. Voojis, "Biodegradable materials in agriculture: case histories and perspectives," in Soil Degradable Bioplastics for a Sustainable Modern Agriculture, pp. 35-65, Springer, 2017.

[7] F. Bader and S. Rahimifard, "Challenges for industrial robot applications in food manufacturing," in ISCSIC '18 Proceedings of the 2nd International Symposium on Computer Science and Intelligent Control, Stockholm, Sweden: ACM New York, NY, USA, 2018.

[8] M. Düsseldorf, The global packaging industry. Interpackalliance.de, 2016, https://www.interpack.com/cgi-bin/md_ interpack/lib/pub/object/downloadfile.cgi/Factbook_GB .pdf?oid=65528\&lang=2\&ticket=g_u_e_s_t.

[9] M. Cerqueira, J. Teixeira, and A. Vicente, "Edible Packaging Today," Edible Food Packaging: Materials and Processing Technologies, 2016, CRC press Boca Raton, FL, 2016.

[10] M. Mathlouthi, Food Packaging and Preservation, Springer Science \& Business Media, 2013.

[11] J. W. Han, L. Ruiz-Garcia, J. P. Qian, and X. T. Yang, "Food packaging: a comprehensive review and future trends," Comprehensive Reviews in Food Science and Food Safety, vol. 17, no. 4, pp. 860-877, 2018.

[12] A. Nura, "Advances in food packaging technology-a review," Journal of Postharvest Technology, vol. 6, no. 4, pp. 55-64, 2018.

[13] M. S. Sibomana, T. S. Workneh, and K. Audain, "A review of postharvest handling and losses in the fresh tomato supply chain: a focus on sub-Saharan Africa," Food Security, vol. 8, no. 2, pp. 389-404, 2016.

[14] I. Majid, G. Ahmad Nayik, S. Mohammad Dar, and V. Nanda, "Novel food packaging technologies: innovations and future prospective," Journal of the Saudi Society of Agricultural Sciences, vol. 17, no. 4, pp. 454-462, 2018.

[15] S. Mangaraj, A. Yadav, L. M. Bal, S. K. Dash, and N. K. Mahanti, "Application of biodegradable polymers in food packaging industry: a comprehensive review," Journal of Packaging Technology and Research, vol. 3, no. 1, pp. 77-96, 2019.

[16] T. O’Brine and R. C. Thompson, "Degradation of plastic carrier bags in the marine environment," Marine pollution bulletin, vol. 60, no. 12, pp. 2279-2283, 2010.

[17] H. Webb, J. Arnott, R. Crawford, and E. Ivanova, "Plastic degradation and its environmental implications with special reference to poly (ethylene terephthalate)," Polymers, vol. 5, no. 1, pp. 1-18, 2013.

[18] N. P. Mahalik and A. N. Nambiar, "Trends in food packaging and manufacturing systems and technology," Trends in food science \& technology, vol. 21, no. 3, pp. 117-128, 2010.

[19] A. Ivankovic, K. Zeljko, S. Talic, A. M. Bevanda, and M. Lasic, "Biodegradable packaging in the food industry," Archiv für Lebensmittelhygiene, vol. 68, pp. 26-38, 2017.

[20] H. Chbib, M. Faisal, A. El Husseiny, I. Fa, and N. ME, “The future of biodegradable plastics from an environmental and business perspective," Modern Approaches on Material Science, vol. 1, no. 2, 2019.

[21] L. Atarés and A. Chiralt, "Essential oils as additives in biodegradable films and coatings for active food packaging," Trends in Food Science and Technology., vol. 48, pp. 51-62, 2016.
[22] M. Kantola and H. Helen, "Quality changes in organic tomatoes packaged in biodegradable plastic films," Journal of Food Quality., vol. 24, no. 2, pp. 167-176, 2001.

[23] A. Ali, M. Maqbool, S. Ramachandran, and P. G. Alderson, "Gum arabic as a novel edible coating for enhancing shelflife and improving postharvest quality of tomato (Solanum lycopersicum L.) fruit," Postharvest Biology and Technology, vol. 58, no. 1, pp. 42-47, 2010.

[24] C. Medina-Jaramillo, S. Estevez-Areco, S. Goyanes, and A. López-Córdoba, "Characterization of starches isolated from Colombian native potatoes and their application as novel edible coatings for wild Andean blueberries (Vaccinium meridionale Swartz)," Polymers, vol. 11, no. 12, p. $1937,2019$.

[25] R. Sanaa and R. Medimagh, "Applications of modified biomonomers and biomaterials: a prospective from Africa," Current Opinion in Green and Sustainable Chemistry, vol. 18, pp. 124-132, 2019.

[26] K. Cherono and T. Workneh, "A review of the role of transportation on the quality changes of fresh tomatoes and their management in South Africa and other emerging markets," International Food Research Journal., vol. 25, no. 6, pp. 2211-2228, 2018.

[27] H. P. S. Abdul Khalil, A. Banerjee, C. K. Saurabh et al., "Biodegradable films for fruits and vegetables packaging application: preparation and properties," Food Engineering Reviews., vol. 10, no. 3, pp. 139-153, 2018.

[28] N. E. Suyatma, A. Copinet, L. Tighzert, and V. Coma, "Mechanical and barrier properties of biodegradable films made from chitosan and poly (lactic acid) blends," Journal of Polymers and the Environment., vol. 12, no. 1, pp. 1-6, 2004.

[29] A. Jiménez, M. J. Fabra, P. Talens, and A. Chiralt, "Effect of lipid self-association on the microstructure and physical properties of hydroxypropyl-methylcellulose edible films containing fatty acids," Carbohydrate Polymers., vol. 82, no. 3, pp. 585-593, 2010.

[30] A. M. Youssef and S. M. El-Sayed, "Bionanocomposites materials for food packaging applications: concepts and future outlook," Carbohydrate polymers., vol. 193, pp. 19-27, 2018.

[31] B. Khan, M. B. K. Niazi, G. Samin, and Z. Jahan, "Thermoplastic starch: a possible biodegradable food packaging material-a review," Journal of Food Process Engineering, vol. 40, no. 3, p. e12447, 2017.

[32] A. El-Anany, G. Hassan, and F. R. Ali, "Effects of edible coatings on the shelf-life and quality of Anna apple (Malus domestica Borkh) during cold storage," Journal of Food Technology., vol. 7, no. 1, pp. 5-11, 2009.

[33] E. . J. Salas-Méndez, A. Vicente, A. C. Pinheiro et al., "Application of edible nanolaminate coatings with antimicrobial extract of Flourensia cernua to extend the shelf-life of tomato (Solanum lycopersicum L.) fruit," Postharvest Biology and Technology, vol. 150, pp. 19-27, 2019.

[34] W. N. S. Mior Azmai, N. S. A. Latif, and N. M. Zain, "Efficiency of edible coating chitosan and cinnamic acid to prolong the shelf life of tomatoes," Journal of Tropical Resources and Sustainable Sciences, vol. 7, no. 1, pp. 47-52, 2019.

[35] J. S. Won, S. J. Lee, H. H. Park, K. B. Song, and S. C. Min, "Edible coating using a chitosan-based colloid incorporating grapefruit seed extract for cherry tomato safety and preservation," Journal of food science, vol. 83, no. 1, pp. 138-146, 2018. 
[36] C. Lombardelli, K. Liburdi, I. Benucci, and M. Esti, “Tailored and synergistic enzyme-assisted extraction of carotenoidcontaining chromoplasts from tomatoes," Food and Bioproducts Processing., vol. 121, pp. 43-53, 2020.

[37] D. Cukrov, "Progress toward understanding the molecular basis of fruit response to hypoxia," Plants., vol. 7, no. 4, p. 78, 2018.

[38] S. Nottagh, J. Hesari, S. H. Peighambardoust, R. RezaeiMokarram, and H. Jafarizadeh-Malmiri, "Effectiveness of edible coating based on chitosan and Natamycin on biological, physico-chemical and organoleptic attributes of Iranian ultra-filtrated cheese," Biologia, vol. 75, no. 4, pp. 605-611, 2020.

[39] M. Causse, J. Zhao, I. Diouf et al., "Genomic Designing for Climate-Smart Tomato," in Genomic Designing of ClimateSmart Vegetable Crops, pp. 47-159, Springer, 2020.

[40] X. Liu, Y. Gao, H. Yang et al., "Pichia kudriavzevii retards fungal decay by influencing the fungal community succession during cherry tomato fruit storage," Food Microbiology, vol. 88, p. 103404, 2020.

[41] M. Gharezi, N. Joshi, and E. Sadeghian, "Effect of post harvest treatment on stored cherry tomatoes," Journal of Nutrition \& Food Sciences., vol. 2, no. 8, pp. 1-10, 2012.

[42] A. Walaszczyk, I. Jałmużna, and J. Lewandowski, Production management and packaging: food safety and industry 4.0. in ICPM-PP, 2019.

[43] J. C. Huang, A. S. Shetty, and M. S. Wang, "Biodegradable plastics: a review," Advances in Polymer Technology., vol. 10, no. 1, pp. 23-30, 1990.

[44] N. Tai, R. Adhikari, R. Shanks, and B. Adhikari, "Aerobic biodegradation of starch-polyurethane flexible films under soil burial condition: changes in physical structure and chemical composition," International Biodeterioration and Biodegradation, vol. 145, no. 11, p. 104793, 2019.

[45] J. M. Bhatnagar, G. Sabat, and D. Cullen, "The foliar endophyte Phialocephala scopiformis DAOMC 229536 secretes enzymes supporting growth on wood as sole carbon source," BioRxiv, vol. 4, no. 10-25, p. 354365, 2018.

[46] A. Tampau, C. González-Martínez, and A. Chiralt, "Biodegradability and disintegration of multilayer starch films with electrospun PCL fibres encapsulating carvacrol," Polymer Degradation and Stability., vol. 173, p. 109100, 2020.

[47] S. Affes, H. Maalej, I. Aranaz, N. Acosta, Á. Heras, and M. Nasri, "Enzymatic production of low-Mw chitosan-derivatives: characterization and biological activities evaluation," International Journal of Biological Macromolecules., vol. 144, pp. 279-288, 2020.

[48] A. L. Prajapat, P. Das, and P. R. Gogate, "A novel approach for intensification of enzymatic depolymerization of carboxymethyl cellulose using ultrasonic and ultraviolet irradiations," Chemical Engineering Journal., vol. 290, no. 3, pp. 391-399, 2016.

[49] C. Medina Jaramillo, T. J. Gutiérrez, S. Goyanes, C. Bernal, and L. Famá, "Biodegradability and plasticizing effect of yerba mate extract on cassava starch edible films," Carbohydrate Polymers., vol. 151, no. October, pp. 150-159, 2016.

[50] D. Parra, J. Fusaro, F. Gaboardi, and D. S. Rosa, "Influence of poly (ethylene glycol) on the thermal, mechanical, morphological, physical-chemical and biodegradation properties of poly (3-hydroxybutyrate)," Polymer degradation and stability, vol. 91, no. 9, pp. 1954-1959, 2006.
[51] X. Huang, T. Mu, C. Shen, L. Lu, and J. Liu, "Effects of biosurfactants combined with alkaline conditions on volatile fatty acid production and microbial community in the anaerobic fermentation of waste activated sludge," International Biodeterioration and Biodegradation., vol. 114, no. October, pp. 24-30, 2016.

[52] I. Mnif, R. Sahnoun, S. Ellouz-Chaabouni, and D. Ghribi, "Application of bacterial biosurfactants for enhanced removal and biodegradation of diesel oil in soil using a newly isolated consortium," Process Safety and Environmental Protection., vol. 109, no. 11, pp. 72-81, 2017.

[53] S. G. Giteru, B. Cridge, I. Oey, A. Ali, and E. Altermann, "Invitro degradation and toxicological assessment of pulsed electric fields crosslinked zein-chitosan-poly (vinyl alcohol) biopolymeric films," Food and Chemical Toxicology., vol. 135, p. 111048, 2020.

[54] K. Nilsuwan, P. Guerrero, K. de la Caba, S. Benjakul, and T. Prodpran, "Properties and application of bilayer films based on poly (lactic acid) and fish gelatin containing epigallocatechin gallate fabricated by thermo-compression molding," Food Hydrocolloids, vol. 105, no. 8, p. 105792, 2020.

[55] C. L. Luchese, N. Sperotto, J. C. Spada, and I. C. Tessaro, "Effect of blueberry agro-industrial waste addition to corn starch-based films for the production of a $\mathrm{pH}$-indicator film," International journal of biological macromolecules, vol. 104, no. 1, pp. 11-18, 2017.

[56] S. Mania, M. Cieślik, M. Konzorski et al., "The synergistic microbiological effects of industrial produced packaging polyethylene films incorporated with zinc nanoparticles," Polymers, vol. 12, no. 5, p. 1198, 2020.

[57] G. E. M. Morales and S. M. A. Calle, Best uses of PLA plastic type and agricultural environmental alternatives, EasyChair, 2020.

[58] X. Sun, W. Xu, X. Zhang, T. Lei, S.-Y. Lee, and Q. Wu, “ZIF67@ cellulose nanofiber hybrid membrane with controlled porosity for use as Li-ion battery separator," Journal of Energy Chemistry, vol. 52, no. 1, pp. 170-180, 2020.

[59] R. de Queiroz Antonino, B. Lia Fook, V. de Oliveira Lima et al., "Preparation and characterization of chitosan obtained from shells of shrimp (Litopenaeus vannamei Boone)," Marine Drugs, vol. 15, no. 5, p. 141, 2017.

[60] C. Bangyekan, D. Aht-Ong, and K. Srikulkit, "Preparation and properties evaluation of chitosan-coated cassava starch films," Carbohydrate Polymers, vol. 63, no. 1, pp. 61-71, 2006.

[61] M. Yar, G. Gigliobianco, L. Shahzadi et al., "Production of chitosan PVA PCL hydrogels to bind heparin and induce angiogenesis," International Journal of Polymeric Materials and Polymeric Biomaterials, vol. 65, no. 9, pp. 466-476, 2015.

[62] S. Bi, J. Pang, L. Huang, M. Sun, X. Cheng, and X. Chen, "The toughness chitosan-PVA double network hydrogel based on alkali solution system and hydrogen bonding for tissue engineering applications," International Journal of Biological Macromolecules, vol. 146, no. March, pp. 99-109, 2020.

[63] B. Koc, L. Akyuz, Y. S. Cakmak et al., "Production and characterization of chitosan-fungal extract films," Food Bioscience, vol. 35, no. 7, p. 100545, 2020.

[64] A. Tinoco, R. M. Rodrigues, R. Machado, R. N. Pereira, A. Cavaco-Paulo, and A. Ribeiro, "Ohmic heating as an innovative approach for the production of keratin films," International Journal of Biological Macromolecules, vol. 150, no. 3, pp. 671-680, 2020. 
[65] L. Lei, H. Zhi, Z. Xiujin, I. Takasuke, and L. Zaigui, "Effects of different heating methods on the production of protein-lipid film," Journal of food engineering, vol. 82, no. 3, pp. 292-297, 2007.

[66] C. I. A. la Fuente, N. Castanha, B. C. Maniglia, C. C. Tadini, and P. E. D. Augusto, "Biodegradable films produced from ozone-modified potato starch," Journal of Packaging Technology and Research., vol. 4, no. 1, pp. 3-11, 2020.

[67] J. Mantovan, G. T. Bersaneti, P. C. S. Faria-Tischer, M. A. P. C. Celligoi, and S. Mali, "Use of microbial levan in edible films based on cassava starch," Food Packaging and Shelf Life., vol. 18, no. 5, pp. 31-36, 2018.

[68] F. R. Lamm, J. Bordovsky, L. Schwankl et al., "Subsurface drip irrigation: status of the technology in 2010," Transactions of the ASABE., vol. 55, no. 2, pp. 483-491, 2012.

[69] Y. Kikkawa, S. Tanaka, and Y. Norikane, "Photo-triggered enzymatic degradation of biodegradable polymers," RSC advances, vol. 7, no. 88, pp. 55720-55724, 2017.

[70] R. Scaffaro, A. Maio, F. E. Gulino, C. Di Salvo, and A. Arcarisi, "Bilayer biodegradable films prepared by coextrusion film blowing: mechanical performance, release kinetics of an antimicrobial agent and hydrolytic degradation," Composites Part A: Applied Science and Manufacturing, vol. 132, no. 6, p. 105836, 2020.

[71] Z. Yu, B. Li, J. Chu, and P. Zhang, "Silica in situ enhanced PVA/chitosan biodegradable films for food packages," Carbohydrate polymers, vol. 184, no. 3, pp. 214-220, 2018.

[72] H. Hu, R. Zhang, J. Wang, W. B. Ying, and J. Zhu, "Fully biobased poly (propylene succinate-co-propylene furandicarboxylate) copolyesters with proper mechanical, degradation and barrier properties for green packaging applications," European Polymer Journal, vol. 102, no. 1, pp. 101-110, 2018.

[73] S. M. Chisenga, T. S. Workneh, G. Bultosa, and B. A. Alimi, "Progress in research and applications of cassava flour and starch: a review," Journal of Food Science and Technology, vol. 56, no. 6, pp. 2799-2813, 2019.

[74] R. P. H. Brandelero, M. V. E. Grossmann, and F. Yamashita, "Effect of the method of production of the blends on mechanical and structural properties of biodegradable starch films produced by blown extrusion," Carbohydrate Polymers, vol. 86, no. 3, pp. 1344-1350, 2011.

[75] K. Vaezi, G. Asadpour, and H. Sharifi, "Effect of ZnO nanoparticles on the mechanical, barrier and optical properties of thermoplastic cationic starch/montmorillonite biodegradable films," International journal of biological macromolecules, vol. 124, no. 9, pp. 519-529, 2019.

[76] I. Hammami, K. Benhamou, H. Hammami et al., "Electrical, morphology and structural properties of biodegradable nanocomposite polyvinyl-acetate/cellulose nanocrystals," Materials Chemistry and Physics, vol. 240, no. January, p. 122182, 2020.

[77] M. Shojaee Kang Sofla, S. Mortazavi, and J. Seyfi, "Preparation and characterization of polyvinyl alcohol/chitosan blends plasticized and compatibilized by glycerol/polyethylene glycol," Carbohydrate Polymers, vol. 232, no. 1, p. 115784,2020

[78] X. Liu, Y. Xu, X. Zhan et al., "Development and properties of new kojic acid and chitosan composite biodegradable films for active packaging materials," International Journal of Biological Macromolecules., vol. 144, no. 7, pp. 483-490, 2020.
[79] Z. Yu, B. Li, J. Chu, and P. Zhang, "Silica in situ enhanced PVA/chitosan biodegradable films for food packages," Carbohydrate polymers., vol. 184, no. 5, pp. 214-220, 2018.

[80] X. Zhou, R. Yang, B. Wang, and K. Chen, "Development and characterization of bilayer films based on pea starch/polylactic acid and use in the cherry tomatoes packaging," Carbohydrate Polymers., vol. 222, no. 114912, pp. 114912-114917, 2019.

[81] S. P. S. Aung, H. H. H. Shein, K. N. Aye, and N. Nwe, "Environment-friendly biopolymers for food packaging: starch, protein, and poly-lactic acid (PLA)," in Bio-based Materials for Food Packaging, pp. 173-195, Springer, 2018.

[82] S. Mali, M. V. E. Grossmann, M. A. Garcia, M. N. Martino, and N. E. Zaritzky, "Microstructural characterization of yam starch films," Carbohydrate Polymers., vol. 50, no. 4, pp. 379-386, 2002.

[83] C. A. Gómez-Aldapa, G. Velazquez, M. C. Gutierrez, E. Rangel-Vargas, J. Castro-Rosas, and R. Y. Aguirre-Loredo, "Effect of polyvinyl alcohol on the physicochemical properties of biodegradable starch films," Materials Chemistry and Physics, vol. 239, no. January, p. 122027, 2020.

[84] M. Indumathi, K. Saral Sarojini, and G. R. Rajarajeswari, "Antimicrobial and biodegradable chitosan/cellulose acetate phthalate/ZnO nano composite films with optimal oxygen permeability and hydrophobicity for extending the shelf life of black grape fruits," International journal of biological macromolecules., vol. 132, pp. 1112-1120, 2019.

[85] S. Khamhan, Y. Baimark, S. Chaichanadee, P. Phinyocheep, and S. Kittipoom, "Water vapor permeability and mechanical properties of biodegradable chitosan/methoxy poly (ethylene glycol)-b-poly ( $\varepsilon$-caprolactone) nanocomposite films," International Journal of Polymer Analysis and Characterization, vol. 13, no. 3, pp. 224-231, 2008.

[86] L. Cabedo, J. Luis Feijoo, M. Pilar Villanueva, J. M. Lagarón, and E. Giménez, "Optimization of biodegradable nanocomposites based on aPLA/PCL blends for food packaging applications," in Macromolecular Symposia, Wiley Online Library, 2006.

[87] J.-W. Rhim, S.-I. Hong, and C.-S. Ha, “Tensile, water vapor barrier and antimicrobial properties of PLA/nanoclay composite films," LWT-Food Science and Technology., vol. 42, no. 2, pp. 612-617, 2009.

[88] V. P. Cyras, M. S. Commisso, A. N. Mauri, and A. Vázquez, "Biodegradable double-layer films based on biological resources: polyhydroxybutyrate and cellulose," Journal of Applied Polymer Science., vol. 106, no. 2, pp. 749-756, 2007.

[89] S. J. Modi, Assessing the feasibility of poly-(3-, hydroxybutyrate-co-3-valerate)(PHBV) and poly-(lactic acid) for potential food packaging applications [Master's Thesis], Ohio State University, Columbus, OH, USA, 2010.

[90] A. I. Cano, M. Cháfer, A. Chiralt, and C. González-Martínez, "Physical and microstructural properties of biodegradable films based on pea starch and PVA," Journal of Food Engineering., vol. 167, no. December, pp. 59-64, 2015.

[91] M. C. Pellá, O. A. Silva, M. G. Pellá et al., "Effect of gelatin and casein additions on starch edible biodegradable films for fruit surface coating," Food chemistry., vol. 309, p. 125764, 2020.

[92] A. M. Sajjan, M. L. Naik, A. S. Kulkarni et al., "Preparation and characterization of PVA-Ge/PEG-400 biodegradable plastic blend films for Packaging applications," Chemical Data Collections, vol. 26, p. 100338, 2020. 
[93] V. M. Azevedo, M. V. Dias, S. V. Borges et al., "Optical and structural properties of biodegradable whey protein isolate nanocomposite films for active packaging," International Journal of Food Properties, vol. 20, no. suplement2, pp. 1-10, 2017.

[94] M. S. Samsi, A. Kamari, S. M. Din, and G. Lazar, "Synthesis, characterization and application of gelatin-carboxymethyl cellulose blend films for preservation of cherry tomatoes and grapes," Journal of food science and technology, vol. 56, no. 6, pp. 3099-3108, 2019.

[95] A. Ivonkovic, K. Zeljko, S. Talic, and M. Lasic, "Biodegradable packaging in the food industry," Journal of Food Safety and Food Quality., vol. 68, pp. 26-38, 2017.

[96] I. García-García, A. Taboada-Rodríguez, A. López-Gomez, and F. Marín-Iniesta, "Active packaging of cardboard to extend the shelf life of tomatoes," Food and Bioprocess Technology., vol. 6, no. 3, pp. 754-761, 2013.

[97] S. Y. Lee, S. J. Lee, D. S. Choi, and S. J. Hur, "Current topics in active and intelligent food packaging for preservation of fresh foods," Journal of the Science of Food and Agriculture, vol. 95, no. 14, pp. 2799-2810, 2015.

[98] F. Charles, J. Sanchez, and N. Gontard, "Active modified atmosphere packaging of fresh fruits and vegetables: modeling with tomatoes and oxygen absorber," Journal of Food Science., vol. 68, no. 5, pp. 1736-1742, 2003.

[99] M. M. Berekaa, "Nanotechnology in food industry; advances in food processing, packaging and food safety," International Journal of Current Microbiology and Applied Sciences, vol. 4, no. 5, pp. 345-357, 2015.

[100] H. M. C. Azeredo, C. G. Otoni, D. S. Corrêa, O. B. G. Assis, M. R. Moura, and L. H. C. Mattoso, "Nanostructured antimicrobials in food packaging-recent advances," Biotechnology Journal, vol. 14, no. 12, p. 1900068, 2019.

[101] M. Zhang, X. Meng, B. Bhandari, and Z. Fang, "Recent developments in film and gas research in modified atmosphere packaging of fresh foods," Critical reviews in food science and nutrition, vol. 56, no. 13, pp. 2174-2182, 2015.

[102] R. Gherardi, R. Becerril, C. Nerin, and O. Bosetti, "Development of a multilayer antimicrobial packaging material for tomato puree using an innovative technology," LWT-Food Science and Technology., vol. 72, pp. 361-367, 2016.

[103] P. Kaewklin, U. Siripatrawan, A. Suwanagul, and Y. S. Lee, "Active packaging from chitosan-titanium dioxide nanocomposite film for prolonging storage life of tomato fruit," International Journal of Biological Macromolecules., vol. 112, no. 4, pp. 523-529, 2018.

[104] R. Dobrucka and R. Cierpiszewski, "Active and intelligent packaging food-research and development-a review," Polish Journal of Food and Nutrition Sciences, vol. 64, no. 1, pp. 715, 2014.

[105] R. Ribeiro-Santos, M. Andrade, N. R. . Melo, and A. SanchesSilva, "Use of essential oils in active food packaging: recent advances and future trends," Trends in food science \& technology., vol. 61, pp. 132-140, 2017.

[106] W. N. S. M. Azmai, N. S. A. Latif, and N. M. Zain, "Efficiency of edible coating chitosan and cinnamic acid to prolong the shelf life of tomatoes," Journal of Tropical Resources and Sustainable Science, vol. 7, pp. 47-52, 2019.

[107] P. Scarfato, L. di Maio, and L. Incarnato, "Recent advances and migration issues in biodegradable polymers from renewable sources for food packaging," Journal of Applied Polymer Science., vol. 132, no. 48, pp. 1-11, 2015.
[108] E. L. Bradley, L. Castle, and Q. Chaudhry, "Applications of nanomaterials in food packaging with a consideration of opportunities for developing countries," Trends in food science \& technology, vol. 22, no. 11, pp. 604-610, 2011.

[109] C. G. Otoni, P. J. P. Espitia, R. J. Avena-Bustillos, and T. H. McHugh, "Trends in antimicrobial food packaging systems: emitting sachets and absorbent pads," Food Research International., vol. 83, no. 22, pp. 60-73, 2016.

[110] L. Pearlstein, Absorbent packaging for food products, Google Patents, 1998.

[111] Y. Zhang, R. De Stefano, M. Robine et al., "Different reactive oxygen species scavenging properties of flavonoids determine their abilities to extend the shelf life of tomato," Plant Physiology, vol. 169, no. 3, pp. 1568-1583, 2015.

[112] H. Liu, F. Meng, S. Chen et al., "Ethanol treatment improves the sensory quality of cherry tomatoes stored at room temperature," Food Chemistry, vol. 298, no. 22, p. 125069, 2019.

[113] M. H. Álvarez-Hernández, G. B. Martínez-Hernández, F. Avalos-Belmontes, M. A. Castillo-Campohermoso, J. C. Contreras-Esquivel, and F. Artés-Hernández, "Potassium permanganate-based ethylene scavengers for fresh horticultural produce as an active packaging," Food Engineering Reviews., vol. 11, no. 3, pp. 159-183, 2019.

[114] S. Mansourbahmani, B. Ghareyazie, V. Zarinnia, S. Kalatejari, and R. S. Mohammadi, "Study on the efficiency of ethylene scavengers on the maintenance of postharvest quality of tomato fruit," Journal of Food Measurement and Characterization., vol. 12, no. 2, pp. 691-701, 2018.

[115] G. Agudelo-Rodríguez, D. Moncayo-Martínez, and D. A. Castellanos, "Evaluation of a predictive model to configure an active packaging with moisture adsorption for fresh tomato," Food Packaging and Shelf Life., vol. 23, p. 100458, 2020.

[116] K. Szabo, B.-E. Teleky, L. Mitrea et al., “Active packagingpoly (vinyl alcohol) films enriched with tomato by-products extract," Coatings, vol. 10, no. 2, p. 141, 2020.

[117] B. Kuswandi, "Active and intelligent packaging, safety, and quality controls," in Fresh-Cut Fruits and Vegetables, pp. 243-294, Elsevier, 2020.

[118] M. Vanderroost, P. Ragaert, F. Devlieghere, and B. De Meulenaer, "Intelligent food packaging: the next generation," Trends in Food Science \& Technology., vol. 39, no. 1, pp. 47-62, 2014.

[119] A. Bartkowiak, M. Mizielińska, P. Sumińska, A. Romanowska-Osuch, and S. Lisiecki, Innovations in food packaging materials, in Emerging and Traditional Technologies for Safe, Healthy and Quality Food, L. R. Óscar, Ed., Springer, 2016.

[120] G. Li, Y. Hou, and A. Wu, "Fourth industrial revolution: technological drivers, impacts and coping methods," Chinese Geographical Science., vol. 27, no. 4, pp. 626-637, 2017.

[121] S. Levin, World Economic Forum and the Fourth Industrial Revolution in South Africa, 2018.

[122] J. Sung, "The fourth industrial revolution and precision agriculture," in Automation in Agriculture: Securing Food Supplies for Future Generations., vol. 1, Intechopen, 2018.

[123] E. A. Baldwin, J. W. Scott, C. K. Shewmaker, and W. Schuch, "Flavor trivia and tomato aroma: biochemistry and possible mechanisms for control of important aroma components," HortScience, vol. 35, no. 6, pp. 1013-1022, 2000. 
[124] J. Burlachenko, I. Kruglenko, B. Snopok, and K. Persaud, "Sample handling for electronic nose technology: state of the art and future trends," TrAC Trends in Analytical Chemistry., vol. 82, pp. 222-236, 2016.

[125] J. Li, Y. Fu, X. Bao et al., "Comparison and analysis of tomato flavor compounds using different extraction methods," Journal of Food Measurement and Characterization., vol. 14, no. 1, pp. 465-475, 2020.

[126] A. Fredes, C. Sales, M. Barreda, M. Valcárcel, S. Roselló, and J. Beltrán, "Quantification of prominent volatile compounds responsible for muskmelon and watermelon aroma by purge and trap extraction followed by gas chromatography-mass spectrometry determination," Food chemistry., vol. 190, pp. 689-700, 2016.

[127] Y. Cai, Z. Yan, L. Wang, M. NguyenVan, and Q. Cai, "Magnetic solid phase extraction and static headspace gas chromatography-mass spectrometry method for the analysis of polycyclic aromatic hydrocarbons," Journal of Chromatography A., vol. 1429, pp. 97-106, 2016.

[128] P. R. Cortina, R. Asis, I. E. Peralta, P. D. Asprelli, and A. N. Santiago, "Determination of volatile organic compounds in Andean tomato landraces by headspace solid phase microextraction-gas chromatography-mass spectrometry," Journal of the Brazilian Chemical Society., vol. 28, no. 1, pp. 30-41, 2016.

[129] O. Zuloaga, N. Etxebarria, B. González-Gaya, M. Olivares, A. Prieto, and A. Usobiaga, "Stir-bar sorptive extraction," in Solid-Phase Extraction, pp. 493-530, Elsevier, 2020.

[130] M. Peris and L. Escuder-Gilabert, "A 21st century technique for food control: electronic noses," Analytica chimica acta, vol. 638, no. 1, pp. 1-15, 2009.

[131] Q. Lu, J. Wang, A. H. Gomez, and A. G. Pereira, "Evaluation of tomato quality during storage by acoustic impulse response," Journal of food processing and preservation., vol. 33, pp. 356-370, 2009.

[132] N. P. Shetti, D. S. Nayak, K. R. Reddy, and T. M. Aminabhvi, "Graphene-clay-based hybrid nanostructures for electrochemical sensors and biosensors," in Graphene-Based Electrochemical Sensors for Biomolecules, pp. 235-274, Elsevier, 2019.

[133] M. Sliwinska, P. Wisniewska, T. Dymerski, J. Namiesnik, and W. Wardencki, "Food analysis using artificial senses," Journal of agricultural and food chemistry, vol. 62, no. 7, pp. 14231448, 2014.

[134] M. Podrażka, E. Bączyńska, M. Kundys, P. S. Jeleń, and E. Witkowska Nery, "Electronic tongue-a tool for all tastes?," Biosensors, vol. 8, no. 1, p. 3, 2018.

[135] F. Mehri-Talarposhti, A. Ghorbani-HasanSaraei, H. KarimiMaleh, L. Golestan, and S.-A. Shahidi, "Determination of bisphenol in food samples using an electrochemical method based on modification of a carbon paste electrode with $\mathrm{CdO}$ nanoparticle/ionic liquid," International Journal of Electrochemical Science, vol. 15, pp. 1904-1914, 2020.

[136] A. Kisiel, B. Baniak, K. Maksymiuk, and A. Michalska, "Turnon fluorimetric sensor for water dispersed volatile organic compounds - A nanosponge approach," Sensors and Actuators B: Chemical, vol. 311, no. 5, p. 127904, 2020.

[137] M. A. Pereira-Barros, M. F. Barroso, L. Martín-Pedraza et al., "Direct PCR-free electrochemical biosensing of plant-food derived nucleic acids in genomic DNA extracts. Application to the determination of the key allergen Sola 17 in tomato seeds," Biosensors and Bioelectronics., vol. 137, pp. 171-177, 2019.
[138] G. Gianquinto, F. Orsini, G. Pennisi, and S. Bona, "Sources of variation in assessing canopy reflectance of processing tomato by means of multispectral radiometry," Sensors, vol. 19, no. 21, p. 4730, 2019.

[139] G. Sun, Y. Ding, X. Wang, W. Lu, Y. Sun, and H. Yu, "Nondestructive determination of nitrogen, phosphorus and potassium contents in greenhouse tomato plants based on multispectral three-dimensional imaging," Sensors, vol. 19, no. 23, p. 5295, 2019.

[140] D. Bicanic, I. Vrbić, J. Cozijnsen, S. Lemić, and O. Dóka, "Sensing the heat of tomato products red: the new approach to the objective assessment of their color," Food Biophysics, vol. 1, no. 1, pp. 14-20, 2006.

[141] Z. Haddi, A. Amari, A. O. Ali et al., "Discrimination and identification of geographical origin virgin olive oil by an enose based on MOS sensors and pattern recognition techniques," Procedia Engineering., vol. 25, pp. 1137-1140, 2011.

[142] A. H. Gómez, G. Hu, J. Wang, and A. G. Pereira, "Evaluation of tomato maturity by electronic nose," Computers and Electronics in Agriculture., vol. 54, no. 1, pp. 44-52, 2006.

[143] X. Hong and J. Wang, "Use of electronic nose and tongue to track freshness of cherry tomatoes squeezed for juice consumption: comparison of different sensor fusion approaches," Food and Bioprocess Technology., vol. 8, no. 1, pp. 158-170, 2015.

[144] A. Z. Berna, J. Lammertyn, S. Saevels, C. D. Natale, and B. M. Nicolaï, "Electronic nose systems to study shelf life and cultivar effect on tomato aroma profile," Sensors and Actuators B: Chemical, vol. 97, no. 2-3, pp. 324-333, 2004.

[145] D. Zhu, X. Ren, L. Wei et al., "Collaborative analysis on difference of apple fruits flavour using electronic nose and electronic tongue," Scientia Horticulturae., vol. 260, p. 108879, 2020.

[146] C. N. Verdouw, J. Wolfert, A. J. M. Beulens, and A. Rialland, "Virtualization of food supply chains with the internet of things," Journal of Food Engineering., vol. 176, pp. 128-136, 2016.

[147] I. Mania, A. M. Delgado, C. Barone, and S. Parisi, Food packaging and the mandatory traceability in Europe, in Traceability in the Dairy Industry in Europe, Springer, 2018.

[148] J. M. Costa and E. Heuvelink, "The global tomato industry," in Tomatoes, CAB International, Boston, USA, 2 edition, 2018.

[149] X. X. Zhang, H. Qiu, and Z. Huang, Apple and tomato chains in China and the EU, LEI, 2010.

[150] D. Rodríguez-Lázaro, B. Lombard, H. Smith et al., "Trends in analytical methodology in food safety and quality: monitoring microorganisms and genetically modified organisms," Trends in food science \& technology, vol. 18, no. 6, pp. 306319, 2007.

[151] A. Hilbeck, R. Binimelis, N. Defarge et al., "No scientific consensus on GMO safety," Environmental Sciences Europe, vol. 27, no. 1, p. 4, 2015.

[152] M. Turci, M. L. S. Sardaro, G. Visioli, E. Maestri, M. Marmiroli, and N. Marmiroli, "Evaluation of DNA extraction procedures for traceability of various tomato products," Food Control, vol. 21, no. 2, pp. 143-149, 2010.

[153] M. Y. Lim, B. R. Jeong, M. Jung, and C. H. Harn, “Transgenic tomato plants expressing strawberry d-galacturonic acid reductase gene display enhanced tolerance to abiotic stresses," Plant Biotechnology Reports., vol. 10, no. 2, pp. 105-116, 2016. 
[154] X. Chen, X. Li, K. Pang, X. Fan, Y. Ma, and J. Hu, “Dissipation behavior and residue distribution of fluazaindolizine and its seven metabolites in tomato ecosystem based on SAX SPE procedure using HPLC-QqQ-MS/MS technique," Journal of hazardous materials., vol. 342, pp. 698-704, 2018.

[155] B. Kuswandi, "Freshness Sensors for Food Packaging," in Reference Module in Food Science, 2017.

[156] L. Fonseca and C. Cané, Monitoring perishable food, in Advanced Nanomaterials for Inexpensive Gas Microsensors, Elsevier Inc., 2020.

[157] S. Rashmi, A. Raizada, G. Madhu, A. Kittur, R. Suresh, and H. Sudhina, "Influence of zinc oxide nanoparticles on structural and electrical properties of polyvinyl alcohol films," Plastics, Rubber and Composites, vol. 44, no. 1, pp. 33-39, 2014.

[158] S. Neethirajan and D. S. Jayas, "Nanotechnology for the food and bioprocessing industries," Food and bioprocess technology, vol. 4, no. 1, pp. 39-47, 2011.

[159] A. Sionkowska, "Current research on the blends of natural and synthetic polymers as new biomaterials," Progress in polymer science., vol. 36, no. 9, pp. 1254-1276, 2011.

[160] G. Alfian, J. Rhee, H. Ahn et al., "Integration of RFID, wireless sensor networks, and data mining in an e-pedigree food traceability system," Journal of Food Engineering., vol. 212, pp. 65-75, 2017.

[161] L. Kong, M. Xia, X.-Y. Liu, M.-Y. Wu, and X. Liu, "Data loss and reconstruction in sensor networks," in 2013 Proceedings IEEE INFOCOM, 2013IEEE.

[162] S. Cui, E. A. A. Inocente, N. Acosta, H. Keener, H. Zhu, and P. P. Ling, "Development of fast E-nose system for earlystage diagnosis of aphid-stressed tomato plants," Sensors, vol. 19, no. (16, p. 3480, 2019.

[163] S.-M. Cheng, J. Wang, Y.-W. Wang, and Z.-B. Wei, “Discrimination of different types damage of tomato seedling by electronic nose," in ITM Web of Conferences, 2017EDP Sciences.

[164] M. Kasbe, T. Mujawar, S. Mule, P. Prabhakar, A. Shaligram, and L. Deshmukh, "An advanced electronic nose (EN) system: Application to classification of tomato and mint," AIP Conference Proceedings, 2018AIP Publishing LLC.

[165] M. S. Rahman, K. Al-Farsi, S. S. Al-Maskari, and N. A. AlHabsi, "Stability of electronic nose (e-nose) as determined by considering date-pits heated at different temperatures," International journal of food properties, vol. 21, no. 1, pp. 850-857, 2018.

[166] S. Xu, X. Sun, H. Lu et al., "Detecting and monitoring the flavor of tomato (Solanum lycopersicum) under the impact of postharvest handlings by physicochemical parameters and electronic nose," Sensors, vol. 18, no. 6, p. 1847, 2018.

[167] H. Akpolat, M. Barineau, K. A. Jackson, D. P. Aykas, and L. E. Rodriguez-Saona, "Portable infrared sensing technology for phenotyping chemical traits in fresh market tomatoes," LWT - Food Science and Technology, vol. 124, p. 109164, 2020. 